\title{
Mulemba
}

Revista Angolana de Ciências Sociais

6 (11) | 2016

Políticas, direitos e práticas da sociedade e do Estado

\section{Sociedade, Estado, sociedade civil, cidadão e identidade em Angola}

Society, State, civil society, citizen and identity in Angola

Arlindo Barbeitos

\section{OpenEdition}

1 Journals

\section{Edição electrónica}

URL: https://journals.openedition.org/mulemba/1422

DOI: $10.4000 /$ mulemba.1422

ISSN: 2520-0305

\section{Editora}

Edições Pedago

\section{Edição impressa}

Data de publição: 1 maio 2016

Paginação: 121-163

ISSN: 2182-6471

\section{Refêrencia eletrónica}

Arlindo Barbeitos, «Sociedade, Estado, sociedade civil, cidadão e identidade em Angola», Mulemba [Online], 6 (11) | 2016, posto online no dia 01 octobre 2018, consultado o 28 juin 2022. URL: http:// journals.openedition.org/mulemba/1422 ; DOI: https://doi.org/10.4000/mulemba.1422

Este documento foi criado de forma automática no dia 26 janeiro 2021.

Tous droits réservés 


\title{
Sociedade, Estado, sociedade civil, cidadão e identidade em Angola
}

Society, State, civil society, citizen and identity in Angola

\author{
Arlindo Barbeitos
}

\section{NOTA DO EDITOR}

Recepção do manuscrito: 04/03/2016

Conclusão da revisão: 29/04/2016

Aceite para publicação: 15/05/2016

«O poder entregue a ele próprio não poderá produzir outra coisa senão mais poder ainda e a violência exercida em nome do poder (e não da lei) se torna um princípio de destruição que não parará senão quando não houver mais nada a violentar».

Hannah Arendt, Les origines du totalitarisme. L'impérialisme. Paris, Fayard [«Points: Politique»; 125], 1982, p. 33.

«O poder se tornou a essência da acção política e o centro da acção política quando foi separado da

comunidade política que se supunha servir». Hannah Arendt, ibid., p. 34.

1 As duas citações, que abrem este texto, emprestarão o tom a estas considerações acerca da definição do conceito sociedade civil e do quadro mais largo em que ela se integra. Elas foram tiradas de uma aturada e dolorosa meditação, centrada em especial sobre a natureza do regime terrorista do Nazismo, levada a cabo pela célebre filósofa política alemã, naturalizada americana, Hannah Arendt. ${ }^{1} \mathrm{O}$ móbil que induziu a pegá-las consistiu, em 2001, na urgência de reflectir sobre da dramática situação vivida por 
Angola à altura e em sugerir algumas achegas que pudessem ajudar a um debate que contribuísse para a instauração da paz.

2 O paralelismo estabelecido entre poderes e situações tão díspares quanto os da Alemanha fascista e os da Angola pós-colonial perderá a estranheza, se olharmos para cada constelação a partir do ângulo da arbitrariedade, da violência e das respectivas consequências sobre a vida política e social dos cidadãos dos dois países. ${ }^{2}$ Como a nossa experiência do pós-independência sobejamente o demonstra, a veracidade das palavras mencionadas acima não se resume à Alemanha hitleriana.

3 As bem mais modestas considerações que se seguem visarão ainda modalidades de dominação, no entanto, elas quedarão por Angola embora talvez contenham validade para demais quadrantes. Elas se farão sob uma perspectiva singular, designadamente de uma procura retroactiva de instâncias políticas, de figuras e de práticas sociais e políticas que, em alguma medida, concorreram para o desastre que nos aflige. $\mathrm{O}$ intento deste «se debruçar sobre si» reside na vontade de vislumbrar, mesmo se incipientemente, factores angolanos que hajam servido de suporte a estratégias e condutas, internas ou externas, cujo efeito culminou na desgraça actual. o justificativo do olhar assenta na convicção que no diagnóstico do mal se aloja o princípio da cura que, como se depreende, envolve discussão aberta; ou seja, propostas válidas de tratamento e intervenção adequada. Na decorrência do plano, a reflexão tratará, para além de outras coisas, de incidir sobre representações identitárias inerentes às diferentes versões de aç̧ão política em Angola, aflorando então as visões sobre o país que lhes são imanentes. Neste âmbito, se dará particular relevo aos comportamentos autoritários e a modalidades de intervenção político-social, que tanto se podem achar na base do conflito como na sua necessária solução. E daí e por fim, como prova pelo contrário, desejo exemplificar a urgência de uma sociedade civil activa.

O surgimento da ideia da sociedade civil está profundamente vinculado à evolução do pensamento europeu ocidental, especialmente ao Iluminismo britânico e francês e, mais tarde, à filosofia alemã do século XIX; aqui ela toma em Hegel e em Karl Marx as acepções mais elaboradas que, dentre outros, o italiano António Gramsci desenvolve para algumas das actuais (cf. KRADER 1976; GELLNER 1995: 71-79). ${ }^{3}$ Por oposição ao Estado, que aglutinaria a sociedade política, a ideia designa em ambos os filósofos alemães, o domínio em que na sociedade burguesa teriam lugar as relações de mercado e económicas. $O$ seu advento se associa inelutavelmente ao estabelecimento da opinião pública, entendida aqui, segundo Jürgen Habermas, como a possibilidade, ou não, de emitir opiniões divergentes da dos poderes políticos. O seu inevitável corolário, enquanto soma de actos e de pareceres, é a esfera pública (cf. HABERMAS 1971: 28-41). ${ }^{4}$ Esta, ao invés da privada e para além da sua definição jurídica, citando o mesmo autor, consistiria no fórum crítico onde se encontrariam as vozes indispensáveis às práticas de obtenção da verdade, mas independentes da vontade estatal. Reunindo estes dois últimos elementos, a opinião pública e a esfera pública, acharíamos uma noção simples de sociedade civil, como o espaço intermediário de relações e de participações sociais se distinguindo nitidamente dos sectores da economia e do Estado. A independência de sectores, portanto, a liberdade de pensamento e de acção, seria o traço próprio que permitiria transcender a imanência social. A maturidade dessa instância pressuporia a dissolução de solidariedades tradicionais e a especialização de papéis sociais diferenciados que não mais se vergariam a fidelidades de eras passadas. E consegui-lo significaria fazer da sociedade civil igualmente uma sociedade política, ou seja, a que 
não deixa para os aparelhos e para os políticos a obrigação de se preocupar com a res publica, a coisa de todos. ${ }^{5}$

5 Voltando às representações relativas à consciência de si e de outrem; exactamente o material de que elas se fabricam denota logo a dimensão cultural já imanente à comparação assinalada antes. Na Alemanha do passado, tal que na África do presente, foi em nome da cultura que ideologias várias, usualmente reaccionárias ou conservadoras e supostamente viradas para o «antigamente», descobrem ou descobriram justificação para empreenderem acções que não se sabem legitimar por si mesmas e que desembocam na arbitrariedade e no excesso. ${ }^{6}$ Por isso, elas precisavam, ontem ou hoje, do auxílio de acessórios que lhes são distantes e de origem vária cujo único denominador comum se situa na dita cultura.

6 A propósito, Habermas nos elucida que a «concorrência política que se desenvolve em torno deste recurso raro que é o "sentido" reduz o afastamento entre política e cultura» (HABERMAS 1999: 69). ${ }^{7}$ E o também ilustre sociólogo francês Alain Touraine acrescenta, em apoio da mesma ideia, que «é a defesa do sujeito, na sua personalidade e cultura, contra a lógica dos aparelhos e dos mercados que substituiu a luta de classes» (TOURAINE 1994: 168). Estas observações pertinentes bastam para que nos debrucemos sobre uma noção que raramente se define com algum rigor e não unicamente porque ela, pela sua essência múltipla, se furta a explicação precisa mas, sobretudo, porque importa a todos os pescadores em águas turvas que ela paire na vagueza.

7 No escopo estreito deste ensaio, não sobra espaço ou disposição para nos ocuparmos em detalhe de assunto tão difícil e escorregadio embora intrínseco ao tema, portanto, pegarei em definição consagrada e proveitosa, mesmo que de tipo bastante geral. ${ }^{8} \mathrm{De}$ acordo com E. B. Tylor, um dos fundadores da etnologia ou da antropologia social, segundo a terminologia, entende-se por cultura «o conjunto complexo incluindo os saberes, as crenças, a arte, os costumes, o direito, os hábitos assim como toda a disposição ou o uso adquiridos pelo homem vivendo em sociedade» (cf. BONTE e IZARD 2000: 190-196). É óbvio que se englobam neste contexto, simultaneamente universal e particular, as línguas, os símbolos, os códigos diversos de comportamento, os valores, os rituais, as técnicas e os artefactos, ou as roupagens específicos de uma determinada comunidade em qualquer momento da sua história. Enfim, todo o acto, físico ou espiritual, simples ou complexo, provido de sentido executado por um ser humano que se inscreve em uma cultura própria.

8 Neste passo, nos confrontamos com o problema, de certo modo não menor, da identificação dos componentes da cultura onde nos instalamos. E a questão pende para o agravamento devido ao lamentável, porque falso e perigoso ainda que vulgar, equívoco que se preza no pesado erro de imaginar identidades, línguas, costumes, valores, crenças etc. como dados imutáveis de proveniência mítica.

Ora a verdade, como nos esclarece em particular a ciência, é que todos esses elementos têm origem histórica, que poderá ser remota ou desconhecida, e que eles estão submetidos, sem excepção, a uma evolução regida por vectores distintos que muitas vezes escapam ao nosso contrôle. Daí se conclui que Angola e, por conseguinte, a «cultura angolana» correspondem a entidades não fixas que resultam de um processo que teve os seus primórdios, conhece o seu devir e um dia verá o seu termo. No exemplo concreto angolano: o nosso país nasceu do encontro e do desencontro seculares entre África, Portugal e Brasil que, ao longo dos seus multifacetados acidentes, conduziram ao advento da realidade que constituímos. ${ }^{9}$ 
10 A presença, na nossa composição histórica e cultural, de componentes originariamente portugueses e africanos obriga a um confronto, mesmo que fugidio, com a dualidade cultural que do começo nos marca. Creio não merecer dúvida de ninguém que o passado, que moldou a nossa existência singular, só à posteriori tolerará alguma correcção desejável dos seus efeitos eticamente mais condenáveis. Por conseguinte, se o colonialismo como sistema de dominação, por devido motivo, não desfruta entre nós de aceitação, muitas das suas consequências equivalem a factos consumados cuja recusa, ou até menosprezo, equivaleriam a suicídio ou a julgamento inconveniente de si. E foi em toada idêntica, relativa à história africana, que o famoso pensador congolês (Kinshasa) V. Y. Mudimbe, e o estudioso do Congo (Kinshasa), B. Jewsiewicki, declararam, em prólogo para uma seleç̧ão de ensaios, que assentavam sobre o cristianismo os fundamentos da nossa história como saber sistematizado (cf. JEWSIEWICKI e MUDIMBE 1993: 1-11). ${ }^{10}$

11 Esse reconhecimento, aquém e além de convicções religiosas e de apreciações de valor, envolve reconhecimento do factor colonial, como um dos aspectos determinantes da realidade angolana actual. Porém, a admissão da presença da contrapartida europeia, emparceirando ao lado da cultura africana como componente fundadora, mesmo se evidente, não deixa de representar uma afronta para certos populismos primários que assolam a África e dos quais Angola não está isenta.

Para um trato mais lúcido e gentil consigo próprio e com a alteridade, se tornam vitais determinadas operações intelectuais e os estados de espírito que delas brotam que, por infelicidade, não se converteram em prática comum da nossa sociedade, nem dos nossos irmãos africanos. ${ }^{11}$ Elas consistem, por exemplo, no afã da transparência, ou seja a faculdade de tradução recíproca das culturas uma à outra e nos termos definidos por cada uma, e na aceitação positiva em todas as partes da síntese final que nós somos. A importância, para o nosso bem-estar, das operações aludidas, exige um esforço cognitivo permanente que afinal significa acção cívica imprescindível.

13 Esta prática, que poderá até receber invólucro estapafúrdio, almeja denunciar palavrosos arrazoados autenticistas, etnicistas ou racistas que se encubram ou se disfarcem, precisamente por detrás de máscaras, alegadamente «africanas genuínas». Normalmente, esses projectos traem, ao contrário do pretendido, a ausência ou a debilidade do ânimo de lucidez e de reconversão mútua a que há pouco fazia referência. A sua menção se explica pelos fantasmas, particulares ou colectivos, que eles nutrem e, quantas vezes, como expressão de vontades individuais ou de grupo estreito. E imagens fantasmagóricas alimentam tiranias, ou incitam a elas, que por seu turno ameaçam populações inteiras e se opõem a sociedades civis desabrochadas. Em meio a este campo minado, somente a análise sóbria e atenta saberá discriminar a reivindicação justa daquela que, embora bem camuflada, esconda a ambição inconfessável.

$* * * * * *$

Recentemente, o sociólogo africano Achille Mbembe publicou um artigo em que buscava desmontar, para um vasto leque de leitores, mecanismos responsáveis pelo fracasso de diversas tentativas de democratização em África (BEMBE 2000: 20-21). Ele queria outrossim explicitar «esboços de uma democracia à africana» que pudessem contribuir a uma revitalização de um debate premente e, deste jeito, lhe juntar uma achega útil. Um dos pontos-chave do artigo se reporta à deliquescência dos aparelhos do Estado e da economia, que coincidem no tempo e no espaço, e à «informalização» concomitante das suas estruturas respectivas. 
15 Puxando estas ideias para Angola, se constataria de imediato e entre outras coisas que a privatização da economia, organizada até esse momento segundo figurino soviético, e o rude emagrecimento da máquina estatal, obediente antes ao rígido molde "socialista», cedem agora a uma cega docilidade à cartilha neo-liberal de notório cunho anglo-saxão. E toda esta tremenda alteração ocorre sem preparação prévia conveniente. Forçosamente, os efeitos de ruptura e de anomia, sobre as instituições e a sociedade, destas medidas de «desregularização», recomendadas em simultâneo pelo Fundo Monetário Internacional (FMI) e pelo Banco Mundial (BM) ou pelas suas dependências regionais, criaram em Angola e em países vizinhos situações em que, em detrimento da população, o grotesco rivaliza com o trágico.

De facto, a «desinstitucionalização», de que fala Mbembe, não apenas reforça a informalização como esta promove a primeira, engendrando ambas uma ambiência de salve-se quem puder que beneficia poderosos e penaliza os mais frágeis. Desta maneira, somem sem rastro, as magras vantagens que garantiam às maiorias obter um pouco do mal gatafunhado desígnio social implícito à anterior luta pela independência. E isso, não obstante configurações administrativas e sócio-económicas, quantas vezes abstrusas senão brutamente desajustadas.

17 Enrolados nesta onda de desintegração, se encontram muitos indivíduos, provenientes sobretudo de camadas humilhantemente marginalizadas ou diminuídas no período colonial - com frequência demasiado desenvoltos e armados de formação ou de ideologia vacilante - , que haviam topado a ocasião de se afirmarem. E eles se tornaram mais partidários e sobretudo mais iguais que todos os outros companheiros de combate e, naturalmente, que os restantes compatriotas. Para estes, a acumulação de poder caminhou de mão na mão com as de riqueza e de prestígio possibilitando, por conseguinte, a colocação das premissas para o enriquecimento posterior. Tal evolução teve lugar durante a fase «revolucionária», quando o discurso socialista fomentava a atribuição e redistribuição de meios de produção, de bens e de serviços no seio de agrupamentos determinados que o compromisso político veiculava e o «sofrimento» experimentado no decurso da luta anti-colonial - na guerrilha, na prisão, no exílio ou na clandestinidade - legitimava.

18 A mudança não perturbou muito estas pessoas que foram percebendo as oportunidades inéditas que a passagem para um novo padrão político, económico e social acarretava. Nesta andança, bastantes dos que apregoavam as qualidades do Marxismo de estilo soviético, depressa, invocavam sem pejo as virtudes do liberalismo que, de facto, os libertava das responsabilidades assumidas anteriormente. A prevaricação até se achava premiada, pois mesmo o discurso e a prática oficiais e oficiosas incentivavam a iniciativa privada que, entretanto, condizia com os seus intentos. ${ }^{12}$ Se o esboroamento do Estado, da economia «socialista», a «informalização» e o enfraquecimento das instituições convinham a um importante estrato social que já havia amontoado capital e mando ou influência ansiados, ele tangia sem apelo todos aqueles que a contingência transmudara em gente não rapidamente rentável ou melhor não monetarizável. ${ }^{13}$

No rescaldo da operação, como explanei, se sacrificaram aqueles não de imediato aproveitáveis para os poderosos, mas imprescindíveis ao funcionamento da sociedade, enquanto totalidade singular, como funcionários, quadros de profissões tais que professores, especialistas vários, operários, camponeses, pastores ou pescadores. $\mathrm{Na}$ verdade, quase todo o povo se torna desta feita entidade descartável, a usar ou a botar fora conforme a conveniência. Um dos resultados mais bizarros desta 
instrumentalização, onde o lucro a curto prazo impera sem comiseração, se patenteia ostensivamente na metamorfose da guerra em, ao mesmo tempo, meio de acção e empresa derivada. E isto, apesar do conflito persistir, enquanto fenómeno maior pelos seus efeitos contraditórios, visto destrutivos e intoleravelmente «construtores» -, na reformulação geral do povo angolano como colectivo humano.

Estas considerações, que provavelmente parecerão sair fora do tema que me proponho tratar, entram nele, porque, por tendência e por constituição, os interesses imediatistas, senão intrínsecos a transações ilícitas daqueles que ganham com o estado de coisas descrito, chocam com a edificação de um Estado respeitador de todos e com uma sociedade civil segura de si e activa. Ora o Estado, na sua qualidade de conjunto de instituições, "deriva de uma fusão ou coligação de forças sociais e não somente de puro processo de racionalização de estruturas políticas». Por consequência, ele «já não pode ser encarado à priori como um árbitro neutro e totalmente autónomo». Ou antes, deveríamos «apreendê-lo como uma instância articulada com uma estrutura conflituosa, mais ou menos dependente de forças particularistas» (cf. BADIE e BIRNBAUM 1944: 95).

Realmente, em tais circunstâncias, a eclosão de uma sociedade civil vigorosa pressupõe um Estado de Direito, que por seu turno, se baseia na dominação da Lei que, em comunidade complexa e moderna, não existe fora da autoridade reconhecida de instituições estatais coerentes. Por sua vez, estas unicamente alcançam plenitude quando, mediante o suporte delas, se logra atingir um nível largamente abrangente de um substrato político-social sólido e esclarecido. E este pressupõe uma sociedade civil capaz de conceber uma «razão pública livre» e de se amparar nela. ${ }^{14}$ Mediante o recurso a esta, se deveria conseguir chegar a uma plataforma consensual e contratual mínima acerca dos direitos fundamentais dos cidadãos e de um catálogo de princípios básicos da organização do Estado angolano.

É evidente que estes pressupostos gerais de uma existência digna só conseguiriam preencher as expectativas, explícitas ou implícitas, da ampla maioria da população, em condições de liberdade e de paz. Também julgo claro que liberdade e paz se caracterizam, em primeiro lugar, como ausência de coerção e de guerra e que a definição pela negativa, de certa maneira, se dirige contra o Estado. Este deveria possuir a robustez suficiente para aguentar e estabelecer o contexto jurídico e político que autorizasse a emergência de conteúdos mais substanciais dos dois conceitos que urge transformar em realidade palpável e assertiva.

23 Essa exigência reclama, no entanto, que os cidadãos adquiram consciência de que o Estado não se pode nunca colocar acima dos direitos dos indivíduos e que ele apenas equivale a um instrumento que alguns deles, em determinadas circunstâncias históricas, construíram para gerir os seus interesses que podem, ou não, coincidir com os gerais. Todavia, a este respeito, a atitude esclarecida cede terreno perante a opacidade herdada do obscurantismo, imanente à ideia de Estado alimentada pelo regime colonial, e impregnando as propostas nacionalistas que o afastaram, ou pretendiam substituir.

Com efeito, se em princípio, o regime colonial recusava ao dominado sequer a mínima vantagem de uma sociedade civil, o sistema soviético, fundindo em desfavor do todo social sociedades política e civil, inflava a primeira e achatava a segunda. Por desgraça, tão-pouco os programas dos partidos do contra-poder ofereciam alternativas emancipadas e dignas, pois que os maiores também eram fiéis ao modelo do partido único e da ditadura que dele advém. Além disso, de acordo com a grelha sociológica de 
Max Weber, estão subjacentes a todas essas forças angolanas formas de dominação tradicional de tempera patriarcal patrimonial que retiram ao cidadão comum o arbítrio pessoal sobre a coisa pública. ${ }^{15}$ Como herança deste passado, prevalece entre nós uma série de duros obstáculos que se metem no caminho do esclarecimento do cidadão.

De um lado, como em toda a parte, estes fenómenos pertencem a processos que se nos apresentam como naturais, ou embrulhados em mitos remotos que lhes transmitem a sacralidade $e$, assim, a autoridade emprestada às coisas de mais-velhos portadores de uma cultura mais propriamente africana. ${ }^{16}$ Contudo, por outro, o conhecimento e a experiência que asseguraram o saber e a técnica que originaram objectos tais que automóveis, aviões, televisões, antibióticos ou aparelhagens e... canhões, também provocaram uma profunda reflexão sobre o ser humano e a vida, manifesta nas humanidades e nas ciências sociais. Conquanto todo esse amontoado de artefactos nos haja chegado inicialmente de fora, ele corresponde na actualidade a um acervo de bens materiais de que a maioria de nós, mesmo que não goze desgraçadamente do seu usufruto, não abdica. ${ }^{17}$ Porém, graças ao património das referidas ciências humanas e sociais, nós sabemos que os distintos poderes, estrangeiros e locais, igualmente aparecem, vivem e desvanecem. Ora, esse corpus de conhecimentos «moles» surgiu, ao mesmo, tempo que matemáticas, físicas, químicas, biologias e técnicas variadas, precisas para a fabricação das mencionadas coisas e, de algum jeito, traduz uma postura reflectida face a esse reverso julgado mais substancial e vantajoso por pessoas menos atentas. ${ }^{18}$

Dita reflexão nos revela o porquê das colonizações e, por exemplo, da incompetência, ou competência limitada, que inevitável e conscientemente as potências europeias produziam entre os dominados. De outro modo, o colonialismo deixaria de constituir a dominação perversa que foi. Mas, ela nos mostra ainda que os males que nos atingem e no meio deles sobressaem os conflitos bélicos, arrastam consigo o pesadume fatal de excessivos vícios da soberania anterior. Por isso, eles ressumam, para o estudioso atento à história real de Angola, o ressaibo rançoso de um já visto, agora em formato mais caricatural e dramático.

Se o saber, que está na origem dos objectos que nos seduzem se nos afigura útil, a introspecção crítica, sua irmã de nascença, assume para muitos de nós ares de arreganho ou de arremedo clandestino, algo de subversivo, de esquisito ou de pior. Como se verifica, aí não se distinguem forças coloniais, de ditaduras e de contrapoderes africanos e nacionais; todos se dão as mãos em macabra roda de dominantes e de especuladores que temem, ou temeram, perder vantagens confortáveis ou lucrativas. Todos se reencontram em deambulação de horror...

Os colonizadores, mesmo que guardem uma responsabilidade histórica que quantas vezes sacodem de si obscenamente, não podem continuar a abarcar bastantes das culpas que nos incumbem entretanto. De facto, não fomos capazes - e não só nós angolanos - de conceber e concretizar uma alternativa à sociedade colonial, autónoma, virada para si, sem ser angolanocêntrica, aberta e viável, pois só pusemos do avesso ou arrumámos de esguelha o padrão social que antes nos havia torcido a alma e o corpo. Em seguida, o remendámos, ajuntando retalhos daqui e dali; «negritude», «revolução», «marxismo-leninismo», «autenticidade», «democracia», «sistema parlamentar», "economia social de mercado», «multipartidarismo», «sociedade civil», etc.

Enfim, agarrámos em toda uma quantidade de ideias e até lugares comuns, oferecidos pela circunstância e pela moda, que anteriormente, ou nos estavam vedados, ou não 
apresentavam para nós incentivo suficiente para os encarar a sério. Contentes, muitos, e ingénuos, demasiados, críamos, tantos, haver erguido algo que permitiria queimar etapas e alcançar em breve um estado de quase beatitude. O contrário do previsto, aconteceu, já que e a progressão no futuro, de que sempre esperámos melhoria, à medida que ia se convertendo em presente e passado, se transformava em desilusão, dor e miséria crescentes. É provável que se haja chegado ao fundo do abismo, no entanto para o assunto tratado tal possibilidade não interessa, pois o único que importa é regressar lentamente e com paixão, mas livre de polémica, ao passado e ao ponto de partida dos erros que cometemos. Esse método impõe que se vá gradualmente do mais recente ao mais antigo e que, sem outra contemplação que pela verdade, se indaguem os motivos de tanto falhanço.

Espreitando detrás das citações de Hannah Arendt da abertura e de demais autores que mencionarei, se descortina uma estupefacção, repleta de desconsolo e de revolta diante do sofrimento gratuito infligido pelo homem a si mesmo. Contudo, a meditação realizada pelos autores africanos de que me socorri não se justifica menos pela repulsa de uma situação, igualmente de horror, a nossa de africanos e de angolanos. Se o ímpeto da indignação irrompe de conceitos de justiça que se sentem feridos por uma realidade odiosa, ela não prescinde, apesar disso, da convicção de que o desastre não se deve a uma fatalidade inadiável de que a África teria o triste apanágio.

31 É precisamente por isso que convém teimar sobre a certeza de que o Estado não constitui senão o instrumental, que indivíduos em sociedade se dão a si e a esta, para que se encarregue de funções primordiais à sua preservação. E o Estado angolano, em país devastado pela guerra civil que a rapacidade internacional atiça e a inépcia do grosso da sua classe política prolonga, claudicou para além daquilo a que o simples bom-senso consegue aquiescer. As tarefas estatais, como as concernentes à saúde, à educação, à justiça ou à segurança social e a tantas outras incumbências de utilidade pública, impõem, pela sua complexidade e pela sua envergadura, ao aparelho institucional e à sua direcção que não se desfaçam de um papel corrector, imprescindível para as classes desprotegidas. Aquelas não podem, ser em exclusivo abandonadas a instâncias privadas que obrigatoriamente movidas pelo lucro só à margem lhes saberiam acudir. ${ }^{19} \mathrm{E}$ isto se mantém válido, até por causa de uma compreensão inteligente e a longo prazo do interesse próprio de quem manda...

A falta de alternativa que valha o nome, a necessidade de diálogo e uma experiência, que nos recomenda evitar a todo preço certo tipo de veleidades «revolucionárias» como muitas cometidas em 1975, nos empurram para um pragmatismo prudente e responsável que se aproximaria da antítese da conduta anterior. E esse procedimento, que é urgente, teria, de início, que se aproveitar das estruturas e parcialmente dos homens actuais e de os reformar progressivamente por dentro. De facto, os problemas se avolumam tanto que correm risco de alcançar aquele grau crítico em que, como metástases de um corpo canceroso, se auto-reproduzissem de tal forma que não tivessem outra solução senão a morte. É claro que extinção significaria desaparecimento como organismo social estruturado, possuidor de um sentido compartilhado de vida. Da argumentação se conclui, parafraseando Gérard Mairet, que todo o Estado tem que se fundamentar sobre uma relação «de todos ao justo político», mas igualmente se infere que, sentindo o cidadão que a prática, daquele onde se ele inscreve, padece desse preceito ético, se levanta abrupta a questão da legitimidade e do Estado de Direito (cf. MAIRET 1997: 191-192). 

não responderão decentemente às solicitações populares se a isso não forem impelidas por grupos crescentes de cidadãos que elas não consigam difamar facilmente. Assim, o método mais correcto consistiria em encetar um contínuo e multifacetado processo de protesto que, a despeito de tudo, soubesse obedecer às regras da não-violência e do respeito que a cada um cabe, a começar pelo adversário. Porém, esse protesto não será obra do acaso, porque requer madura fixação de objectivos, de parceiros e de formas de debate e de acção que terão sempre que conservar o seu carácter público, civil e pacífico.

No artigo de jornal evocado acima, Achille Mbembe discrimina, como um factor maior nos derradeiros fracassos, a ausência de «modelos teóricos, de tradição de reflexão crítica e autónoma acerca do Estado de Direito, as formas da cidadania e as instituições da democracia no continente». Vale sublinhar que, subjacente e em muitas outras ocasiões patente, o seu último livro, relativo à «pós-colónia», contém um longo questionamento do colonialismo e da resposta africana que tomou o seu lugar (cf. MBEMBE 2000). Para além de possíveis vertentes de opinião, tal obra, convertendo a esperança em ideias autónomas e alternativas, dignas e exequíveis, prossegue o programa esboçado aqui.

$* * * * * *$

Directa ou indirectamente, me ocupei da sociedade e do Estado, de instituições respectivas e de umas quantas práticas que em ambos se integram; agora há que relevar que cada uma de essas entidades resulta de comportamentos específicos dos homens que participam como cidadãos do todo social a que estão imanentes uma e outra coisa, mesmo quando não têm disso consciência. Assim, é no meio daqueles, na sua dimensão concreta de africanos e angolanos que, de maneira um tanto impressionista, procurarei topar com um ou outro aspecto de relevância que os caracterize e demarque de demais compatriotas. O objectivo de uma destrinça, que não se furta ao risco de subjectividade abusiva, se reduz a tentativa para melhor entendimento de alguns comportamentos de cidadãos de Estados à busca de vias que satisfaçam os seus interesses individuais e colectivos. E a experiência, a cada instante verificada, não esconde desilusão e descontentamento causados pelas «soluções» saídas da soma das iniciativas empreendidas por toda a parte, mesmo promovidas por instituições internacionais de renome. Aliás, frequentemente, a fama se explica mais pelo poder contido nelas e pela publicidade que ele lhes concede que pela competência ou seriedade demonstradas.

A propósito do Congo ex-francês, Georges Balandier desenvolveu durante os anos cinquenta do século XX o seu conceito, que se tornou clássico, de "situação colonial», que se reporta à vivência do africano sob dominação colonial, dando especial relevo às temíveis rupturas no tecido social que se revelavam em dolorosos exemplos de anomia individual ou grupal. Embora ache a experiência angolana, em alguns aspectos, mais dura que a vizinha contemporânea, os factos descritos encaixam pela sua aspereza completamente dentro do nosso contexto. Seguindo essa lógica, não deveria suscitar admiração a eventualidade de admitirmos que respostas de aparência caótica de tantos angolanos obedeceriam sobretudo a uma matriz colonial autoritária e em essência desumana que desorganizara estruturas anteriores sem repor em seu lugar sistemas congruentes (cf. BALANDIER [1955] 1982: 3-38). ${ }^{20}$

Conquanto escasseiem, por enquanto, estudos que coloquem, para Angola, os factores expostos em perspectiva sociológica, ou social-psicológica, em contextos definidos e consequentes, já temos à disposição trabalhos que nos oferecem uma impressão geral, 
ou tratam casos especiais, da conjuntura africana. $O$ estudo citado de Achille Mbembe acerca da pós-colónia traduz uma das tentativas mais recentes e mais globais de perceber o que se passa connosco. Todavia, malgrado a acuidade e a validade dos contributos, estes reproduzem mais a observação de inter-acções, que se desenrolam em âmbitos político-sociais amplos, escapando ao particular individual que me importa em sua qualidade de sustento do cidadão. ${ }^{21}$ Mas, é com este que se confrontam os dois estudos alemães que me induzirão a permanecer pela sua exemplaridade, e não unicamente porque esta se exprima na excelência das análises que, por isso, alcançaram impacto e respeito universais.

38 A fim de atinar com as causas do nazismo, Alexander Mitscherlich descobre a desorientação de jovens, mesmo de adultos, que entretanto não se reencontram na sociedade da Alemanha saída da industrialização (cf. MITSCHERLICH 1996: 191-204). As transformações haviam atrapalhado os papéis sociais tradicionais e dificultavam os processos conhecidos até aí de identificação, nomeadamente com o pai cuja autoridade se diluía agora. ${ }^{22} \mathrm{Se}$ essas vias facilitavam antes a socialização elas apareciam, posteriormente gastas e sem préstimo notório. $O$ igualmente alemão Theodor Adorno, não menos desejoso de entender o citado fenómeno social e político e situações algures que a ele se assemelhassem, acredita que o "síndroma da autoridade» se revela pela absorção da «repressão social exterior através de um recalcamento íntimo das suas pulsões» (ADORNO data: $37-59$ ). Para ambos, o esvaziamento das maneiras antigas não fora acompanhado de uma liberalização da sociedade que, pelo contrário, guardava uma autoridade que se tornava difusa e se transferia para organizações impessoais.

Imagino que fique claro para o leitor que a configuração social que aflora das duas opiniões serve, outrossim, para perceber o porquê de líderes activos, com pendor para desmesura, e de cidadãos passivos que aceitam, ou anseiam, serem guiados e diminuídos a subalternidade ignominiosa. Querendo, salvaguardadas as devidas distâncias, manter o paralelismo escolhido, acho que podemos sem desprimor da verdade extrapolar para Angola as observações que acabo de expor. Recordo que também o nosso país tivera que enfrentar, de 1890 até a independência, uma viragem do regime colonial cujas consequências, em termos da dimensão da metamorfose social e cultural, se comparam, ou até excedem, a vivida pela Alemanha. Por conseguinte, em independência da diversidade das causas e dos quadros iniciais, se engendraram constelações sociais próximas que forçadamente ocasionaram efeitos idênticos nos habitantes dos territórios abrangidos.

A olho nu, sobressai um aspecto no seio de todos os matizes da ampla gama de programas doutrinários e políticos angolanos; ele é o traço compulsivamente autoritário, quantas vezes violento, que persiste em assomar na paisagem angolana, de outro modo, pacífica e até risonha. Essa característica peculiar ganha com frequência o seu rosto mais brutal, simultaneamente mais rústico, em homens poderosos políticos, negociantes, militares -, cuja deficiente disponibilidade introspectiva se associa a desmesurada ambição compensatória. Neste tipo de personalidade, assaz comum, que cronologicamente desponta durante um dos períodos mais sinistros da nossa comprida e atribulada história colonial, a era salazarenga, se entrecruzam e guerreiam farrapos de diferentes visões ideológicas. ${ }^{23}$

41 A título de exemplo e de forma parcelar, embora não falsa, não seria ousado acreditar que neste angolano se sucedem e se mesclam, em sedimentação caótica, estratos que reproduzem, por fases equivalentes, a crueza e a periodização do processo de 
violentação de que ele foi vítima. ${ }^{24}$ Assim, há que distinguir no espírito do colonizado extractos inseguros do fundo africano magoado, largos retalhos da mensagem patriarcal cristã em sua feição bíblico-messiânica, restolhos dispersos do autoritário discurso oficial, com sua versão quotidiana e mesquinha de soberania de uma nação ibérica fraca e insegura. A essa combinação, que as circunstâncias arrumam, juntam-se cacos tresmalhados de um articulado doutrinário, implícito ou explícito, adquirido no trato desigual com o pequeno colono e, por último, laivos ocasionais de propagandas internacionais que conseguiram transpor o muro colonial de silêncio.

Estes componentes, incoerentes entre si, se compunham e recompunham no íntimo do colonizado, atomizado e isolado por uma potência europeia que, perante ele, se comportava como uma implacável ditadura que mais ostensivamente exibia o seu arsenal repressivo na possessão que na metrópole. Por este facto, qualquer rudimento de opinião própria só seria autorizado ao nativo se ele servisse o regime que aliás optava em geral por prescindir dessas prestações. Tais factores soltos e as consequências traumáticas da sua aglutinação sofriam visível potenciação, em seus aspectos negativos, pelo afastamento das fontes fornecedoras de competência, o ensino diferenciado e a experiência, em que o sistema conservava o dominado. Não esqueçamos ademais, que a exclusão é acessório da colossal e súbita mudança acontecendo ao africano, incluindo esta o esfacelamento de todos os esquemas de referência e de valores em que ele se inseria anteriormente. Na realidade, a colonização o reduzia, na melhor das hipóteses, à humilhação de eterna criança, a moldar segundo o interesse predominante, mas apta pelo corpo de adulto ao trabalho de grandes, embora subalterno devido à pretensa inferioridade mental. ${ }^{25}$

Apesar da posição dura, a rentabilidade do sistema reclamava do dominador o fornecimento de um mínimo de condições materiais ao africano e também de atribuição de competências primárias que permitissem a preservação física da mão-de-obra e os lucros económicos e políticos que assegurassem, não só a reprodução do conjunto como sérias vantagens para Portugal. No entanto, estas concessões se confinavam ao limite da simples subsistência, porque demasiado cedo esbarravam com a estreiteza da metrópole, a debilidade material e cultural dos colonos e a alegada crónica carência de capitais, agravada pelo temor nacionalista de os importar do estrangeiro. ${ }^{26}$ Esse condicionamento das estratégias de acção lisboeta acarretava uma sobrecarga de exploração cujas consequências nefastas se escancaram impiedosamente em $1961 \mathrm{e}$ mais tarde. ${ }^{27}$

A personalidade provinda de um tal condicionamento portaria consigo ingredientes descosidos da sociedade anterior, sujeitos a contínua ameaça de dispersão, que unicamente um autoritarismo rude saberia conter em unidade instável. Na precariedade, residiria explicação para muito da brusquidez de trato e da inconsistência de discurso e de acção por ela demonstrada, principalmente em momentos que ultrapassem balizas conhecidas. Porém, ela revelaria ainda não apenas a insegurança originada pelo estado de anomia herdado da colonização, como também a tentativa desajeitada de superar em seu foro íntimo a imagem interiorizada do exsenhor. Em simultâneo, emanariam dela, para dentro, um sentimento de inferioridade e, para fora, como gesto equilibrante de sentido oposto, uma megalomania inclinada à violência. Como pessoa de poder, presumível agente de Estado ou não, a personalidade examinada trataria de conquistar bases e influência que lhe transmitissem segurança que o compensasse e consolasse. Ela o faria mediante a utilização inevitável de 
mecanismos que recapitulariam procedimentos que a exploraram e a construíram que, por seu lado, forçariam de novo a constelações políticas opressivas. E estas se edificariam em inteiro alheamento ao interesse real das maiorias, mesmo que por artifício e equivoco aquelas as aclamassem.

******* colonialismo como penosamente se pode liberar de uma recentidade que refreia introversão madura. Em seguida, sob o peso da miséria material e espiritual e das suas múltiplas sequelas, essas limitações pioram até a expressão mais trágica ou caricatural. Temos que reconhecer que o indivíduo africano emerge à margem e dos destroços de corpos sociais, com frequência, ao extremo aflitos por mal atroz e teimoso, exercido do exterior e do interior. Como resultado, toda a energia e a imaginação que restam, por vezes assombrosas, se atêm sobretudo a estratégias de sobrevivência. sacudir impedimentos, derivados da diversidade de evoluções, que se postam 
afrontosamente diante dele. A despeito de eles exibirem a prova insofismável da destruição, é bem mais fácil e provável descobrir abrigo nos próprios escombros a que os africanos se viram confrangidos, do que construir casa nova. Deste modo se entendem, sem se aceitarem de bom grado, comportamentos reactivos actuais, como a acentuação obsessiva de representações identitárias, que fornecem refúgio traiçoeiro a tantos que, desamparados, a eles demandam. E, assim, retomando categorias taxionómicas postiças, de origem colonial, a «cobra se morde no rabo» e se eterniza o círculo vicioso da calamidade que temos depressa que contrariar com determinação.

E logo aparece a interrogação que de há muito nos atormenta; como lograria o colonizado alcançar a meditação e o gesto aptos a transcender raiva e ressentimento e a desencantar soluções convenientes para o estrangulamento a que o colonialismo o condenou? A relevância da pergunta se mede simplesmente pela qualidade da luta pela emancipação e das propostas de vida outorgadas, ou melhor impingidas, pelos poderes locais ao africano e ao angolano após as independências. $\mathrm{O}$ desconseguimento, geral e particular, de tão notório, poupa comentários; então, na esteira de outros pensadores africanos, há que questionar, à distância e em pormenor, os traços distintos das soberanias europeias em África e das respostas dos súbditos a elas.

$\mathrm{O}$ alvo almejado não se esgota minimamente em atribuição de culpas, aliás gritantes, e intende, sim, desvelar mecanismos soterrados pelo esquecimento estratégico, ou mais exactamente, pelo recalcamento de que padecem gentes de todos os bordos. Dentre nós, ambos os níveis do olvido denotam excessiva propensão a conservar poderes ilegítimos e abusos que deles advêm, cujas limitações repetem os constrangimentos coloniais que nos foram impostos. Por ocasião da independência, as respostas a uma situação dificílima e as justificações dadas se restringiram sobretudo à urgência de actuar depressa e ao anelo, de cunho milenarista, de chegar à liberdade e ao bem-estar sonhados que saíram, em grande parte, gorados pela envergadura intragável da ingerência internacional que, diga-se de passagem, a inépcia local exacerbou. Mesmo recorrendo aos nossos fracos meios, faltou, visivelmente, a oportunidade de pensar em propostas mais convenientes à solução dos problemas que nos assaltavam.

Possivelmente, a dimensão quiliasta, tão saliente em Angola e em quantos vizinhos, trai a imensa ânsia pelo fim do pesadelo e a correspondente dificuldade emocional e conceptual de o encarar. ${ }^{31}$ De facto, o colonizado reduzido a pura força de trabalho, degradado pelas mutilações feitas à sua cultura e à sua integridade física e moral, enfim atirado para fora de si, apenas em clandestinidade e de maneira disfarçada conseguiria produzir uma reflexão que não estivesse amarrada pelas correntes que o apertavam. ${ }^{32}$ $\mathrm{E}$, frente aos restantes africanos, o angolano se encontrava em desvantagem, atendendo a que Portugal nem aos seus filhos conferia o direito de uma sociedade civil livre e elaborada, quanto mais ao inferiorizado excluído. Refluindo sobre si, esse alimentava violências que um dia tombariam cegamente sobre outrem e sobre si. Apesar disso, o incisivo e assaz peculiar período caetanista, que durou cerca de dez anos, na medida em que reagia a uma guerra de libertação que denunciava os crimes coloniais, foi impelido a instalar os caboucos para uma frágil sociedade civil propriamente angolana.

53 A existência, em 1974, de estratos sociais angolanos providos do bem-estar material mínimo para os subtrair à indigência, composta primordialmente por estudantes, pequenos funcionários, empregados, operários, produtores agrícolas e uns quantos quadros médios e superiores preenchia vários dos critérios básicos para a aquisição da consciência cívica. ${ }^{33}$ Através da leitura de jornais, da audição de rádio, de pequenos 
círculos de discussão no seio de certas igrejas e de centros escolares ou de outras instâncias, como por exemplo grupos clandestinos e heterogéneos de simpatizantes de movimentos nacionalistas, iam gerando processos de informação acerca de si e do mundo.

Este padrão estrutural de evolução, de atitudes e de condutas, que se expressam através do aparecimento de camadas de cidadãos dispondo de um sistema de referências e de valores seguros, constitui substrato indispensável para se chegar a uma opinião pública flexível e diferenciada. A faculdade crítica requerida implica aquele distanciamento de si, enquanto pessoa e grupo, ou seja do interesse singular estreito, que permite forjar opiniões que se acerquem ao máximo da verdade, enquanto representação honesta e tão rigorosa quanto possível do real. Embora este processo reclame, como já expliquei, uma clara individuação, ele não precisa de escolher as modalidades exorbitantes e anómicas de um individualismo narcisista e em excesso egocêntrico, como as se dissimulam nas versões de neo-liberalismo que nos propõem hoje como panaceia. Depois, - por inteligência, em vertentes cívica e ética - a capacidade crítica que se alvitra, recusa veementemente avatares grosseiros e primários de egoísmo individual se pavoneando actualmente em ostentação desabrida por África e por Angola. Enquanto avidez rasteira, essas manifestações a pouco mais equivalem que a feias e rústicas excrescências de uma enviesada e desconseguida restauração de práticas coloniais.

Obviamente, para que depois de 1975, esses primórdios ganhassem maturação a que se aspira, teria sido necessário que demasiados daqueles que se substituíram à soberania portuguesa, ou os que em vão a quiseram, não se aproximassem tanto do bosquejo rudimentar de personalidade autoritária que desenhei. Infelizmente, este me parece uma espécie paradigmática de colonizado que, por este ou aquele móbil, se torna sôfrego de um mando, para o qual ele não detém, quantas vezes, senão a simples e bruta ambição, entretanto munida de armas mortíferas. ${ }^{34}$ De facto, este homem impotente em relação a padrões coloniais interiorizados, já que inapto a resolver intelectual e moralmente as funestas contradições que ele inconscientemente transporta consigo e que o autoritarismo aguenta de pé, apenas reitera os rígidos modelos mentais e de acção que lhe valham para a materialização daquilo que cobiça. Para isso, desde que o consiga, instrumentaliza tudo e todos e, agindo assim, destroça, ou tende a fazê-lo, qualquer indício de emancipação real, porque de outro modo destruiria a possibilidade de manipulação de que, em absoluto, carece.

56 A repetida condenação deste factor humano peculiar, como se ele não dependesse também de contextos mais amplos, quer durante a era da chamada «guerra fria» ou da actual sob a hegemonia dos EUA, deriva antes de um intento, já ressaltado, de introspecção e de auto-crítica. ${ }^{35}$ Esse protesto deseja assinalar a quase inevitabilidade de uma evolução pós-independência a que a manutenção de determinados parâmetros de cepa colonial aduz, porque os aspectos comportamentais censurados confluem obrigatoriamente para condutas altamente prejudiciais para o bem-estar geral. Realmente, a luta pelo poder, a sua aquisição e, principalmente a sua conservação em detrimento de muitos, logo retiram aquela inocência que a condição de espoliado pela opressão colonial à priori exprime. Mas, no caso de persistência, sob o soberano nativo, da situação insuportável, essa perda instiga à culpabilização que compele à denúncia.

57 Esta corresponde a ponto de partida e de chegada de entendimento dos elementos de uma crise cuja resolução é forçada pela integridade espiritual e física dos que nela participam como vítimas ou beneficiados. Senão, perante o fracasso, se insinuam 
demónios excitados pela dúvida de si que, iludindo faltas e motivos autênticos, se exteriorizam em representações levianas de identidade e de alteridade que antecedem ou acompanham caça às bruxas. $\mathrm{E}$ esta exige o estabelecimento arbitrário, ou até terrorista, de semelhanças e de diferenças ilusórias e ridículas, pois que definidas pelas imagens estereotipadas do preconceito que norteiam o personagem em questão. ${ }^{36}$ Daí vem o confinamento às únicas formas de pensar e de actuar que realmente domina $\mathrm{e}$ que se resumem às imanências e às exterioridades das coisas e das pessoas em sua expressão mais fisicamente superficial.

A fim de harmonizar progresso e diversidade no continente, Mwayila Tshiyembe sugeria, há alguns meses, o plano de construir em África o Estado «multinacional», que de acordo com ele, conciliaria o projecto plural e o democrático. $O$ autor utilizava em África, o conceito de «nação» designando uma unidade cultural, linguística e emocional no interior de uma mesma entidade política, como nós o conhecemos, entre outros casos, da antiga União Soviética. Atendendo à importância do assunto, vale a pena citar uma passagem representativa da sua proposta, que dizia que «em ruptura radical com a abordagem clássica, a Constituição fundada sobre os povos - "demótica" ou pluralista - renova a infra-estrutura jurídica e toma em conta o pluralismo para além do multipartidarismo. Ela restitui aos diferentes componentes das sociedades heterogéneas o seu estatuto de povos ou nações, enquanto realidade jurídica e política distinta do estado multinacional». ${ }^{37}$

Sem descartar desde logo, para Angola, essa proposta, quero previamente alertar eventuais incautos para uma complexidade que Mwayila Tshiyembe aparentemente ignora e que reside na própria génese histórica, em seu rosto moderno, das identidades africanas consideradas. De facto, vários são os especialistas de África, em particular africanos e dos mais destacados, que se opõem frontalmente à concepção «etnicista» implícita à tese que ora nos é exposta (cf. AMSELLE e M'BOKOLO 1985). ${ }^{38} \mathrm{~A}$ sua recusa se desenrola ao longo de dois eixos que se resumiriam à conveniência de retorno, em quadro ajustado, à flexibilidade identitária da África pré-colonial e ao abandono de uma rígida dualidade Estado / Nação cuja origem euro-americana e europeia, como o bem demonstra Benedict Anderson, repousa em «comunidades imaginadas» essencializadas (cf. DAVIDSON 1992; ANDERSON 1983: 1-36). ${ }^{39}$

As representações de si, concebidas em certos momentos históricos por elites dos povos correspondentes, teriam justificado independências e valido de esteio ideológico principal para a edificação, ou consolidação, de Estados nacionais. Tais fabricações imaginárias, que embora os mascarassem não deixavam de reproduzir preocupações e interesses singulares, foram incutidas, enquanto categorias substantivas e atemporais, à vasta maioria das populações que as ingeriu. A escola, a literatura, a arte, a ciência e particularmente a imprensa, mais tarde a rádio e a televisão, divulgaram essas imagens normativas por todo o canto dos territórios tangidos e elas acabaram ganhando uma consistência emocional que nos engana acerca da sua natureza. A dimensão de ordem jurídico-política e sócio-económica, que enquanto realidade concreta inevitável, elas rapidamente ganharam, envolvia o cumprimento estrito de um catálogo de prescrições, tidas como patrióticas, para cuja desobediência se previa um estendal de sanções. ${ }^{40}$ No entanto, como nos esclarecem o antropólogo Claude Meillassoux e uns quantos especialistas mais, designadamente africanos, as aludidas identidades somente se cristalizam e agudizam em problema quando o espaço político permitido aos cidadãos se reduz ou fracassa (cf. MEILLASSOIUX data: $9-40){ }^{41}$ 
61 Estudos de carácter geral ou monográfico, efectuados em diversas regiões africanas, indicam uma relativa irrelevância da questão identitária, durante o período préeuropeu e o peso, por vezes asfixiante, que ela tomou no decurso da dominação externa e posteriormente (cf. VAIL 1984; igualmente, BOECK 1986: 75-106; RANGER 1986: 271-281). ${ }^{42}$ Com base na evolução histórica e cultural do Ocidente, a Europa e as Américas exportaram depois para o resto do mundo receitas identitárias contingentes e dúbias que nos foram impostas como superiores, ubíquas e perenes. Convencida da sua infalibilidade toda uma mesnada de governantes, funcionários, eclesiásticos, de todas as confissões confundidas, mestres-escola, colonos, cientistas, literatos, artistas e simples curiosos botou mãos à obra, a fim de redefinir as colónias em concordância com o seu mostruário e vantagem. Entretanto, uma inteira geração de intelectuais, combatentes pela independência, dirigentes políticos, escritores africanos e grossas fatias da opinião pública dos seus países começaram acreditando que o produto da construção artificial e ainda fresca das representações sobre as suas terras e gentes reflectia realidades inabaláveis (cf. KANNEH 1998). ${ }^{43}$

Um processo paralelo ao descrito antes, para Estados ocidentais, teve lugar em Portugal e depois, em versão invertida e adaptada ao desígnio de diminuir o autóctone, foi transferido para Angola. E, como se constata, ele foi abundantemente reverberado por angolanos despojados daquele espírito crítico que a gravidade do assunto aconselharia a desenvolver. Na verdade, o principal das ideias que nós actualmente fazemos de nós e dos outros remonta a uma dramática viragem da política de Lisboa em relação às colónias que terminou abruptamente com o ideário paternalista benevolente do Liberalismo que, dentro do âmbito de uma cidadania portuguesa em África, pugnava pela colaboração da coroa com determinados intermediários nativos (cf. BARBEITOS 2000: 559-614). As visões anteriores do homem negro e de si produzidas pelas elites portuguesas e as suas práticas coloniais foram substituídas por novas que, nada ou demasiado pouco devendo ao universalismo das Luzes e do Catolicismo professado por vários políticos liberais, petrificaram identidade e alteridade em raças e etnias arrumadas em iníquas hierarquias de valor.

63 A mudança doutrinária coincidiu com uma tremenda transformação do espaço submetido a Lisboa, causada pela Conferência de Berlim (1884-1885), onde se entrosaram, pela primeira vez em Angola, sob soberania portuguesa directa, zonas de velha presença portuguesa e outras em que aquela exercia apenas alguma influência através de camadas várias de angolanos providos, ou não, da cidadania citada. ${ }^{44}$

o propósito da reforma consistia em, a exemplo do Brasil, incentivar o povoamento branco da dependência e a incrementar a sua rentabilidade económica que, para bem da metrópole, teria que se converter em eficiente fazenda produtora de artigos tropicais destinados aos mercados nacional e estrangeiro. Para as populações locais, tão tamanha modificação resultava em completa destruição de qualquer autonomia, arregimentação e fixação em espaços específicos, entrada em economia monetária e de mercado e subjugação a uma ordem mental e física completamente inédita. ${ }^{45}$ Para isso, se empreenderam "guerras de pacificação», se aplicaram tributos, como o famigerado «imposto de cubata», se fizeram reformas administrativas, que incluíam a instauração de províncias (os antigos distritos), se promulgaram códigos de trabalho, se instalou um incipiente sistema de ensino e, muito especialmente, se introduziu de maneira coerciva uma diferente noção de homem. 

em particular a última, como Norton de Matos que, na qualidade de Governador-Geral, nomeou em 1912 o etnólogo formado em Paris, José de Oliveira Ferreira Diniz, para o posto de Secretário dos Negócios Indígenas. ${ }^{46}$ Utilizando vivências pessoais e inquéritos, não raro questionáveis, executados por agentes administrativos, ele levou a cabo a tarefa indispensável à ambiciosa missão de elaborar o primeiro levantamento sistemático e exaustivo dos povos angolanos. ${ }^{47}$ Intimamente reunida a este empreendimento pioneiro veio uma inevitável reforma administrativa, cujo alcance foi tal que, em parte, ainda serve de molde para a correspondente divisão da República de Angola. Por intermédio desta medida, ele cobriu o território de uma vasta e estreita malha de circunscrições administrativas que entregava ao poder oficial os instrumentos precisos para tomar realmente posse da colónia. Terminada esta incumbência, Norton de Matos resolveu «organizar o trabalho em Angola, regulamentar em todos os seus pormenores [...]. Contratos, salários, horas de trabalho, alimentação, vestuário, assistência médica $[. ..] \gg{ }^{48}$

Desta feita, desde o exterior e dentro de um contexto ideológico e político específico, se realizaram intervenções sobre a população que equivaleram a instantes decisivos na fabricação teórica e prática da identidade moderna angolana. Em contraste com o passado, se implantava uma modalidade de dominação, envolvendo por conseguinte um modelo de relação entre os homens, que divergia nitidamente do que se vira até aí. Como consequência, se produziram clivagens, que as novas divisões administrativas, as práticas e o discurso do quotidiano cimentavam, que desembocavam em crescente isolamento, atomização e crispação dos indivíduos e dos povos reduzidos à condição de instrumentos de trabalho (cf. MESSIANT 1983; PÖSSINGER 1986: 75-158).

É natural que o sentimento de impotência e abandono experimentado incitasse a procurar refugio em identidades que, não obstante a novidade da expressão, continham algo de conhecido, como a língua e alguns rasgos culturais que haviam restado da transformação. Assim, tais características trazidas do antigamente e em aparência imutáveis, teriam servido de substrato para desenvolvimentos posteriores que conduziram à receptividade daquilo a que o discurso colonial apelidou de «raças» e de «tribos», sendo estas, por eufemismo, mais tarde promovidas a «etnias» (cf. FIGUEIRA 1938). ${ }^{49} \mathrm{E}$, ao longo da senda errada, se sucedeu à arbitrária brutalidade colonial a abusiva violência angolana...

\section{À laia de epílogo}

68 A despeito das suas mais que movediças ambiguidades, as identidades têm provocado problemas que apenas constrangimentos destrutivos, como os que acabámos de evocar, conseguem explicar. Ora, urge que não só se desmascare esse estado de coisas, como ainda que se indiquem ao cidadão angolano encaminhamentos para a uma solução eficaz dos seus conflitos. A proposta que aqui se enuncia consiste em passar a delicada questão identitária para a esfera privada de cada um e exigir que se concedam garantias constituicionais a essa transferência que julgo viável. De facto, se os angolanos aceitaram que a religião, que com frequência vem ligada a ela, pertencesse ao foro individual, como não admitir que aí se colocasse também a mencionada consciência de si e as representações que ela instiga. 
69 Assim, se prosseguiria uma secularização há muito iniciada no Estado Ocidental, que por enquanto nos vale de modelo, que ajustaríamos nesse capítulo à nossa conveniência. Contudo, essa alteração do imaginário e das práticas comportamentais $e$ jurídicas envolvidas reclamaria que, em acto complementar, se escolhessem modalidades de organização estatal que se afastassem da matriz jacobina, autoritária e rigidamente unitária, do Estado-Nação que nos é apresentada como a única capaz de reter a unidade do território e dos angolanos. Por sua vez, as ideias avançadas envolvem posicionamentos próximos àquilo a que Habermas, temente dos deploráveis efeitos do nacionalismo na Europa e em alusão à Republica Federal da Alemanha, chama «Verfassungspatriotismus» (Patriotismo Constitucional) que ele logicamente integra na esfera do Estado de Direito, multipartidário e parlamentar. ${ }^{50}$ No nosso caso, tendo em vista as contradições reais e facciosas que nos separam, conviria que a lealdade constitucional se legitimasse em debate franco da Lei Fundamental, da estrutura organizacional do território angolano e das instituições que favorecessem uma convivência harmoniosa. Assim, se poderia conferir ao Patriotismo Constitucional aquela base consensual, abrangente o bastante, para que ele obtenha a robusta substância contratual de inúmeras vontades compartilhadas.

70 Este enfeixamento de propostas, a discutir, poderia representar uma saída apropriada ao endurecido espartilho da dualidade de Estado/Nação, oriunda de um autoritário e rígido modelo ocidental desgastado, pois que as guerras fratricidas e sanguinárias que tal concepção de ordenamento de povos e de seus espaços territoriais provocou, tornam mais que duvidosa, arriscada e injusta. Ademais, a época em que já entrámos, de globalização económica, de concentração da soberania em grandes constelações políticas e de homogeneização cultural, a fragiliza, senão, a longo prazo, a transforma em algo obsoleto e perigoso.

71 E, para reforço do programa, é bom que um mais profundo conhecimento da história e da cultura africana pré-coloniais nos auxilie a achar sugestões apropriadas a um relacionamento equilibrado, amigável e coeso entre geral e particular, diversidade e identidade. ${ }^{51}$ Também não causará mal lembrar que, como a África antiga, a Europa anterior à Revolução Francesa, a Ásia, que ia do Império Otomano à China dos Manchus, e a América pré-colonial englobavam sem excepção largos e poderosos Estados multinacionais. Isto, porque, ao invés do que muitos crêem, a salvaguarda da integridade de grupos singulares - e repito, a África pré-colonial o comprova -, recebe bastantes vezes mais garantias em vastos Estados plurais que em pequenas entidades políticas fortemente centralizadas e fechadas sobre si. Aqui, o maior problema, aliás bem duro de roer, que se coloca à variante de Estado recomendada reside na organização de um poder central robusto e representativo; ou seja um centro em que todos os cidadãos se revejam e que possua autoridade e competência para gerir a sociedade e a economia de modo a assegurar uma base de bem-estar geral. A dimensão utópica do desígnio e o facto das doutrinas políticas actualmente prevalecentes se oporem a esta visão, não nos devem impedir que ele constitua um ponto de partida de uma reflexão cujo resultado - quem sabe? - possa um dia se converter em lugar de chegada. Há portanto que repensar séria e publicamente todo um conjunto de assuntos que nos dizem respeito e que, de jeito nenhum, podem em exclusivo ser entregues a uma classe política que, em sua maioria, provou insuficiências dramáticas.

72 Para que estas propostas recebam o exame que merecem, haveria a urgência de fomentar o advento de uma opinião pública política, que assente em razão pública livre, 
fosse capaz de encetar o processo de criação de opiniões e de vontades tendentes à elaboração das premissas indispensáveis a uma rápida e sólida reconciliação que saiba associar a esperança de paz democrática a níveis dignos de riqueza económica e de harmonia social compartilhadas. É premente, para os filhos de Angola, que a pujança da sua terra passe de potencialidade a fonte real de prosperidade merecida e, para que isso aconteça, é obrigatório que se quebre uma lógica de doentio selo colonial que a flagela desde 1975. Com efeito, ela tem que renegar de vez ao jogo fatal de uma dicotomia medíocre e cruel baloiçando entre, de um lado, a prepotência alarve de chefe-de-posto abusador e o seguidismo matumbo de cipaio vingativo e, do outro, entre o tosco pretensiosismo de fubeiro endinheirado e o servilismo tortuoso de servente desprovido.

E agora, voltando ao começo da exposição, quero salientar que o desenvolvimento da opinião pública, da esfera pública, portanto da sociedade civil, espelha ele mesmo os meandros e os baixios deste se debruçar sobre si e sobre o mundo em que os seus participantes andam metidos. Desta feita, dentro e fora de Angola, os propósitos que aqui se patenteiam em seu desenrolar fenomenológico são eles já um acto comprovante da necessidade imperiosa da sociedade civil e da sua existência, mesmo se ainda deveras incipiente.

\section{BIBLIOGRAFIA}

ADORNO Theodor W., 1982, Studien zum autoritären character. Frankfurt am Main, Suhrkamp Verlag.

AMSELLE Jean-Loup e M'BOKOLO Elikia (dir.),1985, Au coeur de l'ethnie. Ethnies, tribalisme et État en Afrique. Paris, Éditions La Découverte [«Textes à l'appui»].

ANDERSON Benedict, 1983, Imagined communities. Reflections on the origin and spread of Nationalism. Londres e New York, Verso.

APPIAH Kwame Anthony, 1992, My father's house. Africa in the Philosophy of Culture. Londres, Oxford University Press.

APPIAH Kwame Anthony \& GUTMANN Amy, 1996, Color conscious. The political morality of race. New Jersey, Princeton University Press.

ARENDT Hannah, 1982, Les origines du totalitarisme. L'impérialisme. Paris, Fayard [«Points: Politique»; 125].

BADIE Bertrand e BIRNBAUM Pierre, 1994, Sociologie de l'État. Nouvelle édition augmentée d'un préface. Paris, Hachette [«Pluriel»].

BALANDIER Georges, 1982 (4. edição) [1955], Sociologie de l'Afrique Noire. Dynamique sociale en Afrique Centrale. Paris, Presses Universitaires de France [«Quadrige»].

BARBEITOS Arlindo, 2000, «Oliveira Martins, Eça de Queiroz, a raça e o homem negro», in Maria Emília Madeira Santos (dir.), A África e a instalação do sistema colonial (c.1885-c. 1930). Actas da III 
Reunião Internacional de História de África. Lisboa, Centro de Estudos de História e Cartografia Antiga; Instituto de Investigação Científica Tropical, pp. 559-614.

BOEK Filip De, 1996, «Postcolonialism, power and identity: local and global perspective from Zaire», in Richard Werbner and Terence Ranger (ed.), Postcolonial Identities in Africa, Londres \& New Jersey, Zed Books, pp. 75-106.

BONTE Pierre e IZARD Michel (dir.), 2000, Dictionnaire de l'Ethnologie et de l'Anthropologie. Paris, Presses Universitaires de France [«Quadrige»].

CAETANO Marcello, 1954, Os Nativos na Economia Africana. Coimbra, Coimbra Editora Limitada. CHRÉTIEN Jean-Pierre e PRUNIER Gérard (dir.), 1989, Les ethnies ont une histoire. Paris, Éditions Karthala; ACCT - Agence de Coopération Culturel e Technique.

DAVIDSON Basil, 1992, The black man's burden. Africa and the curse of the Nation-State. Oxford, James Currey; Harare, Baobab Books; Nairobi, NEAEP; Kampala, Fountain Publishers.

DINIZ José de Oliveira Ferreira, 1918, Populações indígenas de Angola. Coimbra, Imprensa da Universidade.

DINIZ José de Oliveira Ferreira, 1926, «Orientação de Portugal na política indígena de Angola. Conferência proferida na Sociedade de Geografia de Lisboa a 4 de Maio de 1926», Boletim da Agência Geral das Colónias (Lisboa), Ano II, n.ํ13, Julho, pp. 46-75; Ano II, n.ำ14, Agosto, pp. 73-96. DOUGLAS Mary, 1969, «Is matriliny doomed in Africa?», in Mary Douglas \& Phylis M. Kaberry (ed.), Man in Africa. Londres, New York, Sydney, Toronto, Wellington, Tavistock Publications, pp. 121-135.

ELIAS Norbert, 1997, La société des individus. Paris, Fayard, [«Agora: Pocket»; 163] [Die Gesellschaft der Individuen, 1987].

FANON Frantz, 1961 (1. edição), Les damnés de la terre. Préface de Jean-Paul Sartre; présentation de Gérard Chaliand. Paris, François Maspero [Paris, Gallimard, 1991; Paris, Folio («Actuel»; 25), 1998].

FIGUEIRA Luiz, 1938, África Bantú. Raças e Tribos de Angola. Lisboa, Oficinas Fernandes.

FOUCAULT Michel, 1975, Surveiller et punir. Naissance de la prison. Paris, Gallimard [«Tel»; 225].

GELLNER Ernest, 1995, Condições da liberdade. A sociedade civil e seus rivais. Tradução de Maria Carvalho. Lisboa, Gradiva.

IGNATIEFF Michael, 1997, The warrior's honor: Ethnic war and the modern conscience. New York, Metropolitan Books \& Henry Holt \& Co.

KRADER Lawrence, 1976, Dialect of civil society. Assen \& Amsterdão, Van Gorcum [Frakfurt am Main, Suhrkamp, 1976].

HABERMAS Jürgen, 1999, Écrits politiques. Culture, droit, histoire. Paris, Flammarion [«Champs»] [Título original: Kleine politische schriften, V, VI, VII. Frankfurt am Main, Suhrkamp Verlag, 1985, 1987, 1990].

HABERMAS Jürgen, 1992, Die moderne ein unvollendetes projekt. Philosophisch-politisch aufsätze. Leipzig, Reclam Verlag [Frankfurt, Suhrkamp Verlag, 1981, 1.․ edição].

HABERMAS Jürgen, 1971 (5.. edição), Strukturwandel der öffentlichkeit. Untersuchungen zu einer kategorie der bürgerlichen desellschaft. Neuwied und Berlin, Sammlung Luchterhandm Luchterhand Verlag. 
JEWSIEWICKI B. e MUDIMBE V. Y., 1993, «Africans' memories and contemporary History of Africa», History and Theory, vol. 32, n. 4, Dec., pp. 1-11 [Beiheft 32: History Making in Africa, Wesleyan University].

KANNEH Kadiatu, 1998, African identities. Race, Nation and Culture in Ethnography, Pan-Africanism and Black Literatures. Londres e New York, Routeledge.

MARX Karl, 1953, Die Gesellschaft als bürgerliche Gesellschaft: Die Frühschriften. Herausgegeben von Siegfried Landshut. Stuttgart, Alfred Kröner Verlag.

MATTOS Norton de, 1953, África nossa. O que queremos e o que não queremos nas nossas terras de África. Porto, Edições Marânus.

MATTOS Norton de, 1944, Memórias e trabalhos da minha vida. Factos, acontecimentos e episódios que a minha memória guardou. Conferências, discursos e artigos e suas raízes no passado, vol. III. Lisboa, Editora Marítimo-Colonial, Lda.

MBEMBE Achille, 2000, De la postcolonie. Essai sur l'imagination dans l'Afrique contemporaine. Paris, Édtions Karthala.

MBEMBE Achille, 2000, «Entre coups d'état, élections reportées et mouvements sociaux. Esquisses d'une démocracie à l'africaine», Le Monde Diplomatique (Paris), Octobre, pp. 20-21.

MEILLASSsOUX Claude, 2004, «Fausses identités et démocraties d'avenir», in Patrice Yengo (dir.), Identité et démocratie en Afrique et ailleurs. Paris, L'Harmattan; Point Noire, Association Rupture, pp. 9-40.

MESSIANT Christine, 1983, 1961 L'Angola colonial, histoire et société. Les prémisses du mouvement nationaliste. Thèse de doctorat de 3ème cycle, préparée sous la direction de $\mathrm{M}$. le professeur Georges Balandier. Paris, École des Hautes Études en Sciences Sociales.

MITSCHERLICH Alexander, 1996 (10. e edição), Auf dem Weg zur vaterlosen Gesellschaft.Ideen zur Sozialpsychologie. München und Zürich, Piper Verlag.

NEUMANN Franz, 1937/1954, Demokratischer und autoritärer Staat Studien zur politischen Theorie. Frankfurt am Main, Europäische Verlagsanstalt; Europa Verlag Wien.

PÖSSINGER Hermann, 1986, «A transformação da sociedade umbundu desde o colapso do comércio das caravanas», Revista Internacional de Estudos Africanos (Lisboa), n. ${ }^{\text {os }} 4-5$, JaneiroDezembro, pp. 75-158.

RANGER Terence, 1996, «Postscript. Colonial and postcolonial identities», in Richard Werbner and Terence Ranger (ed.), Postcolonial Identities in Africa, Londres \& New Jersey, Zed Books, pp. 271-281.

RAWLS John, 1996, Le droit des gens. Traduit de l'américain et avant-propos par Bertrand Guillaume et commentaire de Stanley Hoffmann. Paris, Union Général des Éditions [«Bibliothèque 10/18»]; Éditions Spirit 2712.

RAWLS John, 1993, The Law of People, On Human Rights: The Oxford Amnesty Lectures. New York, Basic Books.

RAWLS John, 1973, A theory of justice. Oxford, Oxford University Press.

RICOEUR Paul, 2000, La mémoire, l'histoire, l'oubli. Paris, Éditions du Seuil.

TSHIYEMBE Mwayila, 2000, «L'Afrique face au défi de l'État multinational», Le Monde Diplomatique (Paris), n. .558 , Septembre.

TORRES Adelino, 1991, O Império Português entre o real e o imaginário. Prefácio de Alfredo Margarido. Lisboa, Escher [«Estudos sobre a história»; 5]. 
TOURAINE Alain, 1994, Qu'est-ce que la démocratie? Paris, Fayard.

VAIL Leroy (ed.), 1984, The creation of tribalism in Southern Africa. Berkeley and Los Angeles, University of California Press.

WEBER Max, 1964, Wirtschaft und Gesellschaft. Grundriss der verstehenden Soziologie. Studienausgabe Herausgegeben Von Johannes Winckelmann. Köln und Berlin, Erster Halbband Kiepenheur \& Witsch.

WERBNER Richard and RANGER Terence (ed.), 1996, Postcolonial Identities in Africa. Londres \& New Jersey, Zed Books.

YENGO Patrice (dir.), 2004, Identité et démocratie en Afrique et ailleurs. Paris, L'Harmattan; Point Noire, Association Rupture.

\section{NOTAS}

1. Hannah Arendt, enquanto judia, foi vítima da violência arbitrária subjacente e consequente à fixação da noção de identidade e da sua racialização pelo regime fascista do seu país de origem. Por esse motivo, se viu forçada a abandonar a Alemanha e a buscar refúgio nos Estados Unidos da América (EUA).

2. Àqueles a quem o paralelismo se apresente como insólito, sublinho que parto da peremptória premissa da rigorosa equivalência de todos os seres humanos. Em sua sequência, este pressuposto implica de pronto o reconhecimento de uma universalidade que inclui todas as particularidades humanas enquanto suas partes integrantes. Esta postura fundamental, desde que se estabeleçam os parâmetros em que ela se inscreve, autoriza qualquer comparação entre sociedades.

Saliento que o colonialismo, o racismo e o ódio étnico equivalem sempre a grave entorse ao princípio enunciado, visto eles exagerarem, para além do admissível pela razão e pela ética, as singularidades em detrimento do universal. Tal atitude comporta obrigatoriamente um sentimento narcisista e excessivo de diferença de si face ao outro e o estabelecimento de hierarquias insuportáveis entre os humanos. Por esse motivo, os comportamentos, que daí resultam, vão parar em conflitos mais menos gravosos.

Ver acerca desta problemática, designadamente o que, seguindo Freud, ele denomina «o narcisismo da diferença menor», de Michael Ignatieff (data: 35-71).

3. O livro de Lawrence Krader, a partir de uma perspectiva marxista não-ortodoxa e extremamente erudita fornece, no âmbito das teorias filosóficas, uma vasta visão do processo evolutivo do conceito. Por sua vez, a obra de Gellner importa pelas suas observações acerca da passagem de um sociedade orientada pelo marxismo soviético para uma outra com aspirações democráticas.

4. Do original em alemão, cf. referências bibliográficas no fim do artigo.

5. Parto simplesmente do conceito aristotélico do homem como «animal político».

6. Faço questão de distinguir, mesmo que de maneira precária e insuficiente, entre atitudes ou doutrinas conservadoras das correspondentes «reaccionárias». As primeiras, em princípio, defendem instituições, valores sociais herdados da tradição e formas de autoridade que delas emanam. Conquanto elas tendam a decidir pela conservação do status quo, e a serem apanágio de grupos privilegiados, elas não acarretam obrigatoriamente violência e até conseguem se volver contra ela, pois que factor oposto à ordem que preferem. Com efeito, as ditas correntes podem, sem maior dificuldade inerente, respeitar um quadro político pré-estabelecido que não lhes agrade sobremaneira. Quanto à reacção: esta implica quase por definição, e mais em hipérbole retórica, que realmente retorno a uma situação anterior à vigente. E esta negação não somente leva a congregar constelações heterogéneas e frágeis em torno da recusa como incita, 
frequentemente, a oportunismo na escolha dos meios a empregar para ultrapassar os obstáculos que se levantem à mudança. Deste jeito, e de acordo com o método da facilidade, a força enquanto recurso mais rápido e conveniente ao equilíbrio dos interessados, se oferece como instrumento simples e eficaz de mobilização pública. Na sequência, ela se alia a um outro elemento de facilidade que consiste no uso do imediato e do óbvio que se recusam ao trabalho moroso e mais paciente da compreensão inteligente, que transcende a superfície elusiva da aparência. Neste sentido, a reacção, ao contrário do conservadorismo, se mostra habitualmente avessa ao desenvolvimento de um programa coerente, visto lhe bastar o ataque a uma e qualquer configuração política. Daí, aliás, lhe vem o seu carácter circunstancial que se presta às mais variadas combinações, nomeadamente conservadoras, quando o status quo se torna social e politicamente insuportável e os seus propulsionadores recorrem para o impôr à violência física ou à verbal. Porém, a experiência deste século e do nosso país chega para entender que partidos que se colocam à esquerda do painel ideológico, não raro, empregam expedientes que claramente e sem abuso de linguagem se classificarão como reaccionários.

7. Não esqueçamos que esta questão permanece pertinazmente um assunto actual. Por exemplo, que «sentido» terá a vida para nós perante a persistência da guerra, da miséria e da doença?

8. Referimo-nos a uma concepção lata de cultura e não a um género mais formal e institucionalizado da mesma; em geral apanágio de sociedades detentoras de modalidades escritas de memorização e de comunicação de saberes e de artes.

9. Creio que não custa perceber que toda a humanidade, ainda que em condições diferentes, obedece a este princípio geral e inexorável. $O$ aspecto da colonização não só é comum a todo o nosso continente, como atingiu muitos outros estados do mundo exterior a nós, que se não limitam às Américas ou à Ásia, pois igualmente a Europa o viveu. Se Roma não houvesse colonizado a Ibéria, neste instante, eu não estaria escrevendo em português. Será que este pormenor me induz a indagar a origem pré-moderna ou recente da cultura portuguesa que, independentemente da minha vontade, é porção constituinte da cultura angolana? É óbvio que não, pois no máximo me questionarei acerca da sua operacionabilidade e do seu valor para a obtenção da liberdade e do bem-estar que se coadunem com a maneira de ser que nos ou me caracteriza.

10. O simples facto de usarmos inconscientemente na contagem do tempo marcas ocidentais e não antigos critérios africanos já reforça o pensamento dos dois eruditos.

11. Visamos uma variante de amor-próprio individual e colectivo que considera a alteridade parte de si e que, tendo por isso o diálogo como prática essencial à vida, se fecha à exclusão do outro.

12. Não confundir a, neste momento, justificável e recomendável auto-crítica, atendendo a que circunstâncias e limitações induzem qualquer ao equívoco, com fragilidade ética e de pensamento, que representam aliás uma das heranças coloniais, com o puro oportunismo que em Angola e em demais Estados não poupa nenhuma força política.

Penso estar claro ao leitor que a exposição esquemática, porém não errada em suas grandes linhas, obliterou incorrectamente numerosas excepções ao modelo do "ad hoc", imposto pelos diferentes tráficos que o materializam. Portanto, haveria que integrar entre os principais beneficiários deste desenvolvimento, mais que esquisito, um grupo heterogéneo que, por atacado, engloba bastantes adventícios, estrangeiros e nacionais, que para bem do negócio se coligaram com os senhores políticos e, antes do mais, uma boa porção da nomenclatura do Novimento Popular de Libertação de Angola (MPLA), porém não o corpo inteiro desta e muito menos a totalidade dos seus combatentes e dos seus militantes.

13. Em Angola, seria preferível falar de «dolarização» e parcialmente a «randização» da economia que teria que ser vista em sentido global que obrigatoriamente incluiria sectores «formais», «informais», «legais» e «ilegais». Esta estrangeirização acompanha a deliquescência mencionada e o esmigalhamento social que ela implica. Ela assenta sobre as indústrias de extracção mineira 
que, ainda que de carácter predatório e sob parcial domínio externo, constituem as únicas fontes produtoras de riqueza real na região. Este aspecto de unilateralidade económica acentua a natureza dependente e de propensão parasitária das nossas elites e contra-elites de poder. Constelações próximas se constatam na Nigéria, nos Congos, na Zâmbia, no Zimbabwe, na Namíbia e em outros vizinhos.

14. A expressão é empregada pelo professor Bertrand Guillarme em crítica ao «Direito das Gentes» do famoso jurista norte-americano John Rawls. Ainda que crítico, o docente citado se apoia na obra do segundo. Ver o seu arguto Avant-propos (pp. 33-37), à obra Le droit des gens de John Rawls (cf. RAWLS 1993; e ainda, 1973: 150-161, 162-166).

15. $O$ papel de autoridade paternal, excessivamente personalizada e empolada, concedido à figura do chefe em qualquer destes partidos demonstra a correcção do julgamento. $O$ patrimonialismo, que se infere deste tipo de mando, consiste no açambarcamento dos aparelhos de poder por individualidade unidas ao chefe mais por ligame pessoal que por qualquer outra competência ou qualidade. A fraqueza de instituições que emerge desta configuração política fomenta clientelas, respectivos nepotismos e múltiplas variantes de corrupção. 0 patriarcalismo em questão obedece a velha matriz portuguesa ajeitada à colónia, mas a ele se agregam elementos de senioridade e de reciprocidade aldeã africanas. A combinação provou a sua incapacidade de gerir a sociedade, de estabelecer o Estado de Direito e de imaginar as soluções que necessitamos para Angola, portanto, deve ser descartada (cf. WEBER 1964: 167-178).

16. Esta visão do mundo cristaliza o passado em forma imutável, quer dizer ontologiza erradamente a tradição e a cultura transfigurando-as em categorias estáticas. Como se nós vivêssemos, sentíssemos e nos comportássemos no presente tal como o fazíamos há centenas de anos. Realmente, apesar de permanências, nós, a língua, a cultura, o povo e tantas mais coisas são sempre processos em vias de construção. É óbvio que dessa mudança fica algo de constante que não deve renunciar à sageza tradicional, no entanto, a intelegência consiste em saber distinguir os contextos e em adequar as respostas.

17. Tenhamos sempre em mente que embora enquanto africanos, ou precisamente angolanos, não tenhamos participado, salvo uma ou outra excepção, na feitura directa dessas coisas, o nosso trabalho de escravos ou de seres humanos dominados contribuiu decisivamente para a riqueza do Ocidente que criou tais artigos. Chegou finalmente a altura, não tanto de pedir indemnizações, que envolvem processos não raro ambíguos, mas de conquistá-los pela competência adquirida, sempre que preciso.

Esta capacidade não deveria jamais abandonar a meditação crítica sobre o perigo da reificação dos espíritos que hoje nos muda em entes sobretudo, real ou virtualmente, consumidores e produtores de coisas e serviços. Esse achatamento redutor ocorre quando a razão é diminuída à simples e única condição instrumental e comunicacional de meio indispensável para a materialização dos objectos e dos actos referidos e da manutenção dos sistemas de dominação que nos resumem a tal amputação de nós.

18. Aqui se poderia, por exemplo, lembrar a crítica dirigida contra os assustadores efeitos da técnica, como ciência aplicada, sobre o homem, que levou a cabo a filosofia da chamada «Escola de Frankfurt», incluindo nomes como Adorno, Horkheimer, Habermas entre outros, na sua «Teoria Crítica». Ou em tom diferente, mas assaz acerbo, a posição de Heidegger e de seus numerosos discípulos espalhados pelo mundo afora. E não menos contundentes na desmontagem de uma modernidade, inconcebível sem tecnologias diversas e as práticas a que elas forçam, são também Foucault, Paul de Man, Paul Ricoeur, Levinas ou Derrida e demais «desconstrucionistas». Isto, para não citar senão algumas individualidades destacadas do pensamento ocidental que, entretanto, se vai convertendo em universal, já que pensadores de toda a parte, designadamente africanos, se vão apoderando destas ideias e as repensam de acordo com o questionamento que crêem conveniente ao seu espaço. 
Estes propósitos, de forma nenhuma ficam deslocados em Angola, visto bastar para tanto reconduzir à memória uma série de projectos grandiosos impostos ao país, que obrigatoriamente falharam por não se adequarem aos homens por eles tocados. Contudo, em tais empreendimentos se espelha a espantação ingénua de muitos dos nossos poderosos face às maravilhas do mundo desenvolvido, que eles ingenuamente admiram e atabalhoadamente pretendem repetir. Contudo, para disso se mostrarem capazes, teriam que dominar muitos dos pressupostos requeridos para tal que em aparência pouco têm a ver com técnicas. Insediosamente, se revela aqui um difuso e disfarçado complexo de inferioridade que a relação lúdica dessas pessoas, por vezes quase infantil, com esses objectos mágicos não logra escamotear.

19. Há que encontrar um equilíbrio entre sociedade, economia e Estado que nasce mais do jogo dessas instâncias em si que de um projecto autoritário de planificação central. Este ajustamento recíproco não deve todavia prescindir de directrizes gerais que, tanto quanto a formação dos órgãos representativos do Estado e os da sociedade civil, reclamam debate.

20. Convém esclarecer que a anomia significa estado de isolamento do indivíduo ou de desorganização da sociedade, devido à ausência, contradição ou incongruência das normas sociais. A ordem africana é esmagada pelo regime colonial, provocando deste modo uma situação de caos no mundo dominado à qual o dominador responde com autoridade implacável. 0 colonizado se vê entretanto compelido, sem indulgência, a seguir leis, costumes e maneiras de pensar e de estar que lhe são originariamente estranhas ou até avessas. A imposição da novidade é ainda rudemente sustentada pela arbitrária inferiorização do africano, enquanto ser humano, e consequentemente de todas as suas exteriorizações culturais.

21. Karl Marx, em diversas ocasiões, chamou à atenção para as sérias contradições que, na mesma pessoa, opõem o burguês ao cidadão. Ainda que dentro dos parâmetros desta comunicação se incida sobre o espaço social e suas vertentes políticas, não seria recomendável, por preconceito ideológico ou outro, afastar de nós a pertinência do problema. Na verdade, é exactamente a coincidência que se escancara entre o procedimento desabrido, como agente económico ou político, do tipo de indivíduo em questão e as exigências cívicas da comunidade que levantam duros obstáculos à sociedade civil (cf. MARX 1953: 418-428).

22. O facto de, em quase todas as nossas sociedades «tradicionais», o tio materno possuir o ascendente social considerado não altera o exposto. 0 ponto crucial se situa na perda de sentido de algumas instituições, dos papéis sociais que elas condicionam e, consequentemente, na crise que daí provém e nas respostas que o grupo social lhe oferece. Ver a este respeito o ensaio de Mary Douglas, Is matriliny doomed in Africa? (1969: 121-135).

23. Alguns defensores camuflados, ou mais discretos, do colonialismo e da concepção inaceitável do homem a ele imanente, avançam que no decurso desta época se fizeram progressos, indiscutíveis, nos campos da medicina, sanidade, conhecimento de patologias animais ou vegetais várias e outros. A ingenuidade implícita a esta argumentação mora na incapacidade que ele demonstra em não perceber que tais benefícios são em favor do africano reduzido à condição aviltante de fonte de mão-de-obra e nada mais. Não fosse esse pseudo interlocutor, pouco inteligente, haveria logo entendido a debilidade do argumento e se teria calado. Esta compreensão absolutamente instrumentalizada do homem negro se expressa nas palavras de Marcello Caetano ao afirmar que «[...] os pretos em África têm de ser dirigidos e enquadrados por europeus [...] [eles] são indispensáveis como auxiliares destes» (cf. CAETANO 1954: 16).

24. Não se deve, de jeito nenhum, descurar o aspecto decisivo de que este género de personalidade engloba duas variantes, designadamente a activa, que nos ocupará mais, e a passiva. Ambas as metades se condicionam e uma não vai sem a outra. o lado mais terrível deste fenómeno bifacial, consiste no facto da vítima activa demonstrar compulsiva inclinação a reiterar, invertendo-o, o procedimento de vitimização a que foi injustamente submetido. E o risco de abuso é acrescido porque a massa de passivos aceita ou até se dispõe a seguir o malfeitor. Como anteriormente, são os desprovidos de meios quem mais sofre os desmandos deste fraco 
com trejeitos de força que desta feita reactualiza o drama sofrido e inconscientemente preserva a pior das opções da memória colonial.

Franz Fanon, que verificara a ocorrência, em diversas ocasiões e sob distintas perspectivas a comentou, contudo ele não teve a oportunidade de prosseguir uma investigação que ficou inacabada. Portanto, ele também não teve a ocasião de se confrontar com sequências negativas da sua absolutização da violência libertadora, enquanto única réplica do colonizado à constante agressão do dominador (cf. FANON 1998 [1961; 1993]). Ler sobretudo a parte final.

25. O professor de Direito e de Ciência Política, durante vários anos refugiado do Nazismo nos Estados Unidos da América (EUA), Franz Neumann, em ensaio brilhante, interpreta as nefastas consequências da ditadura de Hitler sobre os seus concidadãos, sobretudo no atinente à atomização e ao isolamento. Ainda que esses se assemelhem à experiência colonial, por infelicidade, a comparação vai em detrimento do africano. Este estaria mais na condição do russo a dominar pelos fascistas, pelo menos a coincidência de conteúdos que ressalta das palavras de Himmler, um dos mais próximos próceres do ditador, com a opinião de Marcelo Caetano acerca do papel dos negros na economia colonial, fala por si. Convém ainda salientar que, a este respeito, o último primeiro-ministro da Ditadura não se apartava de Armindo Monteiro, um dos mentores do Acto Colonial de 1930-1932 ou da postura de Salazar. Para os russos afirmava Himmler que: «[...] tudo o que eles podem aprender é contar até 12 e a escrever o seu nome. Toda a educação que vá para além disto é perigosa e não deveria ser apoiada». Comparativamente, o alemão era progressista, pois, em 1961, pelo menos 95 \% dos angolanos chamados «indígenas» não estariam sequer em situação de assinar o seu nome (cf. Franz Neumann, Demokratischer und autoritärer Staat Studien zur politischen Theorie («Estados, democrático e autoritário. Estudos para a teoria política» - Os textos aqui seleccionados apareceram entre 1937 e 1954 - Frankfurt am Main, Europäische Verlagsanstalt, 1967, pp. 235-237). Para evitar qualquer mal-entendido, há que afirmar que não se destacam aqui graus de crueldade e sim semelhanças de postura face ao outro.

26. O Professor Adelino Torres, após a sua atenta leitura desta comunicação, chamou muito justamente a atenção para o facto, desenvolvido antes em obra sua, de que, a dita penúria de capitais na colónia, correspondia mais a uma política deliberada face à Angola que a uma falta real de capitais. E, a partir da actuação do Banco Nacional Ultramarino, ele exemplifica esse desinteresse consciente de maneira bastante esclarecedora (cf. TORRES data: 91-117).

27. Nenhuma outra análise desta fase do nosso passado mais próximo, descreve tão drástica e objectivamente a miséria da quase totalidade da população angolana, como a de Christine Messiant (cf. MESSIANT Christine, 1961 L'Angola colonial, histoire et société. Les prémisses du mouvement nationaliste. Thèse de doctorat de 3ème cycle, préparée sous la direction de $\mathrm{M}$. le Professeur Georges Balandier. Paris, École de Hautes Études en Sciences Sociales, 1983, pp. 137-158, 381-398).

28. Penso parecer evidente que a questão se ponha aqui em termos abstractos, visto durante a época colonial e através do continente inteiro, ser muitíssimo reduzido o número de intelectuais e quadros africanos capazes de assumirem esta incumbência ingente embora primordial. Por isso, é sintomático que a grande acuidade do problema unicamente seja sentida, com tanta nitidez, bastantes anos volvidos após as independências formais e principalmente na sequência das catástrofes que, sem excepção, nos assolam a todos.

29. Creio claro que tal processo intelectual é, pelo menos, tão velho como o homem moderno, designado por Homo Sapiens Sapiens. Contudo, o grau de profundidade entretanto alcançado reclama grande avanço de divisão do saber, abundante cultura material e modalidades muito elaboradas de organização social em seu sentido mais lato. E, ainda, a faculdade de se colocar perante o espelho da sua consciência e de se olhar minuciosamente. Este persistente desdobramento do sujeito em objecto constitui uma difić́lima operação intelectual que impõe um muito grande distanciamento para consigo mesmo, consequentemente, apenas o consegue isenta de trauma, a personalidade que desabrochou como indivíduo em comunidade já marcada por 
individuação anterior. Depois, há que acrescentar a vasta sedimentação de conhecimento acumulado e objectivado em documentos escritos e organizado em instituições escolares, providas de especialistas, que fomentam o aumento de saber sistemático e auxiliam o processo da reflexão e, assim, de criação individual. Isto porém não significa, de jeito algum, que prevaleça menoridade cerebral em sociedades que escolheram vias diferentes de evolução, visto a mesma capacidade mental que caracteriza todas as variedades humanas saber achar expressão da respectiva singularidade. Agora, em tais configurações sociais, tudo se opõe à individuação que é vista como algo inadmissível e não raro patológico.

30. Ver a propósito os três admiráveis ensaios de Norbert Elias recolhidos em La société des individus (edição alemã 1987; 1. edição francesa 1991; edição presente 1997: 163, passim). Não nos esqueçamos que indivíduo quer dizer «algo que não se divide mais».

31. Nesta mirada retrospectiva, eu me refiro ao período colonial. No entanto, a reacção actual à catástrofe do país não diverge muito do passado. Assim, antes de exprimir uma penúria de categorias analíticas e de opções lúcidas, que seria falta grave iludir, esta atitude mostra a religiosidade profunda de uma população.

32. "Atirar para fora de si» o nativo significa não somente arrancá-lo por inteiro ao contexto político, económico, social e cultural do momento vivido, como também sacá-lo do seu passado. Como resultado, foi negada história ao africano e, deste modo, ele morava fora dela, ou pior, dentro da história colonial, considerada sob o ângulo do seu opressor. E o nosso caso atinge gravidade singular; basta botar uma olhada sobre as ditas «Histórias de Angola», de Cadornega a Ralph Delgado, passando por Elias Alexandre da Silva Corrêa, para o comprovar. Em meu entender, se aninha aqui uma das razões maiores da lamentável ignorância de nós que nos impregna e cujos efeitos me parecem terríveis.

33. Atendendo a que a miséria, quando ela atinge o grau prevalecente em Angola, empurra para a uma nefasta e obnubilante luta pela sobrevivência, se torna claro que um mínimo de desafogo é condição básica para a sociedade civil ágil.

34. A presença deste género de angolano excede, de muito longe, a identificação com qualquer corrente partidária, visto ele existir em todos os partidos e diversos extractos populacionais, para além de toda a pertença identitária. Repito, a meu ver, nós nos confrontamos aqui com um verdadeiro problema nacional que aliás transcende Angola. Portanto, salta por completo fora do contexto visado, culpar especificamente este ou aquele, já que aquilo a que se pretende é melhor compreender atitudes e comportamentos de que continuamos imbuídos que, para o bem da comunidade, devem ser combatidos. O plano deseja explicitar fenómenos que nos dominam, porque preversamente inerentes a nós, cujos reflexos se exteriorizam em diferentes formas de acção e de pensamento anti-sociais. E ele deseja, ainda, em diálogo ajudar a conceber respostas flexíveis e abrangentes que tragam consigo alternativas garantes de paz, de justiça e de solidariedade para todos!

35. Sem me alongar sobre este nexo indiscutível, direi só que estas presenças estrangeiras têm por si a tendência a fazer piorar excessos internos. No entanto, também gostaria de lembrar que não raro somos nós que facilitamos a sua intromissão.

36. Ler a este propósito a nota 4. A nomeação da pretensa «raça» em documentos de identificação angolanos representa um exemplo acabado do tipo de pensamento e acção denunciado por Michael Ignatieff. Como o mostram Kwame Anthony Appiah e mais eruditos africanos actualizados, a noção de raça é absolutamente avessa à tradição verdadeiramente africana. Isto não significa que a diferença não fosse constatada, porém, ela não era cristalizada em falsa e absolutizada biologização de si e de outrem (cf. APPIAH 1992: 28-46. Esta notável obra existe em versão de lóngua portuguesa editada no Brasil. E ainda, APPIAH \& GUTMAN 1996: 30-105).

De facto, aplicado aos humanos, o conceito de raça, como o senso comum o usa por toda a parte a partir de uma ilusória evidência naturalista, não equivale actualmente a nenhuma grandeza científica. Ele se reduz a uma, errada mas divulgada, categoria do pensamento que se crê 
confirmada, a olho nu, pela variedade externa dos traços corporais. Ao contrário do que afirma o preconceito arraigado, que principalmente trai interesse, insegurança e mal-estar consigo mesmo, a diversidade de fenotipos não faz perigar a unidade biológica da humanidade inteira. A noção de ser humano, comum ao mundo chamado bantu antes da colonização e que surge nas nossas línguas como muntu, omanu, mutu etc., não significava qualquer predicado físico ou cultural, visto ela se referir a uma essência humana em si, compartilhada por todos os seres humanos. Contendas, conflitos e diferenças que, como por toda a parte existiam, não punham em dúvida este fundamento. Unicamente a estranha mistura de ciência, de ideologia e preconceito que distinguiram o pensamento ocidental dos últimos séculos, admitido entretanto pelos próprios angolanos, ousaram conspurcar a pureza anterior dos conceitos africanos evocados.

Como elemento de uma visão ágil, a ideia africana original se coadunava melhor que as presentes classificações empedernidas, de origem colonial, europeia, à multiplicidade local e, como se viu, não divergia da perspectiva cientifica mais séria. E ele portava consigo uma forma de humanismo africano que o abuso colonial se, não aniquilou, aviltou e que há que recuperar, já que conveniente à modernidade, que malgrado atrasos patentes, nos impregna. Assim, essa visão que é defendida por eruditos africanos de reconhecido valor, dos quais saliento Wole Soyinka (Nigéria), V. Y. Mudimbe (Congo-Kinshasa), Kwame A. Appiah (Ghana), Elikia M’Mokolo, (CongoKinshasa), Achille Mbembe (Camarões), Jean G. Bidima (Camarões), terá que ser assumida por nós.

37. Mwayila Tshiyembe é director do Institut panafricain de géopolitique de Nancy (cf. «L'Afrique face au défi de l'État multinational», Le Monde Diplomatique (Paris), n. ${ }^{\circ}$ 558, Septembre de 2000.

38. Esta obra pioneira basta para revelar o carácter de construção imaginária artificiosa inerente à percepção actual de algumas etnias africanas. Ver, igualmente, ps artigos de Jean-Pierre Chrétien, «Dimension historique de l'ethnicité en Afrique» e «Sciences Humaines et construction des ethnies» (in 1989: 5-9 e 13-14, respectivamente). Este livro, muito esclarecedor, contando com a colaboração de cientistas africanos, obedece à mesma toada que o prévio.

39. Todo este livro do reconhecido historiador inglês é um libelo contra o chamado Estado-nação em África.

40. Imagine-se, em momento de crise bélica, um pacifista que, negando a dicotomia redutora e injusta que divide humanidade em inimigos e amigos, se recusasse a condenar o chamado contrário!

41. Este útil livro denuncia a futilidade e a irresponsabilidade de estratégias identitárias praticadas por diferentes poderes europeus e africanos e por seus agentes.

42. Estes dois volumes, que incluem artigos de diferentes pesquisadores investigando regiões variadas, elucidam detalhadamente a argumentação dos opositores à tese «etnicista».

43. Esta obra, de autor africano, mostra com sobriedade e saber o carácter perigosamente falacioso de tanta crença identitária, de salobro gosto colonial, que a pobreza mental e ética de amplas classes políticas em África e em Angola debitaram e debitam.

44. Este encaixe reuniu, pela primeira vez sob a mesma autoridade, regiões de há muito sujeitas a um antigo processo de aculturação a outras adjacentes onde este chegava diluído ou simplesmente estava ausente. A operação causou rupturas de representações anteriores que e a adopção do particularizante e isolador figurino europeu seriamente agudizou. A cristalização identitária, que daí proveio, impediu muitíssimos angolanos de enxergar que, desde épocas remotas, um velho fundo linguístico-cultural comum promovia configurações de continuidade e de complementaridade geográficas, históricas, económicas e sociais que a amplitude dos espaços alargava mas que o colonialismo perturbou.

45. A perda da mobilidade anterior, que se espaldava em extensa rede continental de relações e de trocas comerciais, políticas, sociais e culturais, se saldou pela fragmentação. Esse foi pois um dos resultados finais destas operações de disciplina e de domesticação, que têm o corpo / objecto 
do autóctone por alvo, típicas do bio-poder definido por Michel Foucault (cf. FOUCAULT 1975: 159-206).

46. Do Dr. José De Oliveira Ferreira Dinis, antigo deputado e antigo Secretário Provincial de Angola, cf. Orientação de Portugal na política indígena de Angola (Conferência proferida na Sociedade de Geografia de Lisboa a 4 de Maio de 1926, p. 47, e, igualmente, Boletim Geral das Colónias, Lisboa, n.ำ 14, Agosto de 1926).

47. Do Dr. José de Oliveira Ferreira Diniz, Secretário dos Negócios Indígenas Curador Geral da Província de Angola ver, igualmente, Populações indígenas de Angola (1918).

48. Cf. Norton de Mattos, Circular do Governador-Geral de Angola. Em data de 17 de Abril de 1913. Pró-memória. Ponte do Lima (Decreto do Governador Geral relativo à Reforma Administrativa); Norton de Mattos, África Nossa. o que queremos e o que não queremos nas nossas terras de África. Porto, Edições Marânus, 1953, pp. 107-113; Norton de Mattos, Memórias e trabalhos da minha vida (Factos, acontecimentos e episódios que a minha memória guardou. Conferências, discursos e artigos e suas raízes no passado), vol. III. Lisboa, Editora Marítimo-Colonial, Lda, pp. 185-190, 236-240.

49. Depois de Ferreira Diniz, este autor, que não denota sólida formação científica, é um dos primeiros a divulgar a, à altura, recém-criada «carta étnica» angolana para um público vasto, do qual sobressaem os funcionários do quadro administrativo colonial. Não é pois de admirar que se tenha expandido e afirmado uma percepção postiça e nefasta de Angola, para a qual igualmente contribuíram especialistas de renome. Um dos estudiosos que recorre à essa mesma equivocada vulgata é René Pélissier. Ainda que magnífico e útil coleccionador de factos, em particular guerras, o meticuloso historiador sofre da lamentável tendência de extrapolar para o passado categorias do presente e depois de as fixar fora do seu contexto histórico. A sua falsa visão dos grupos linguísticos culturais angolanos demonstra que cientistas europeus, e nem sequer dos menores, aceitaram sem crítica indispensável os mitos identitários que a sua mesma cultura espalhou (cf. PÉLISSIER 1986).

50. Jürgen Habermas se referiu, em várias oportunidades, ao «Verfassungspatriotismus», por conseguinte, me vou cingir a uma obra na qual, sem jamais a mencionar nominalmente, ele expõe de ponta a ponta conteúdos pertinentes à noção (cf. HABERMAS 1992).

51. Em análise luminosa, Paul Ricouer aludia ao olvido e ao perdão que, «separada $e$ conjuntamente» designariam o «horizonte» da pesquisa em que eles se inscreviam. E ele prosseguia, explicando que cada um deles caberia a «problemáticas distintas», nomeadamente, o olvido à da «memória e da fidelidade ao passado» e o perdão à «da culpabilidade e da reconciliação com o passado». Ambos, finalizava ele, comporiam esse «horizonte» cruzado que seria o de «uma memória apaziguada consigo, até de um olvido feliz». Ninguém melhor que o filósofo resumiu a intenção deste trabalho (cf. RICOEUR 2000: 536).

\section{RESUMOS}

A presente reflexão tratará, para além de outras coisas, de incidir sobre as representações identitárias inerentes às diferentes versões de acção política em Angola, procurando sobretudo aflorar as visões sobre o país que lhe são imanentes. Neste âmbito, procurará dar particular relevo aos comportamentos autoritários e as modalidades de intervenção político-social, que tanto se podem achar na base do conflito como na sua necessária solução. Consequentemente, como prova pelo contrário, procurarei exemplificar a urgência de uma activa sociedade civil. 
In addition to other things, the present paper focus on the identity representations inherent to the different versions of political action in Angola, seeking to bring forth visions about the country that are immanent to it. In this context, it will seek to highlight the authoritarian behavior and the modalities of socio-political intervention, which can be both found at the root of the conflict and in its necessary solution. Consequently, on the contrary, I shall try to exemplify the urgency of an active civil society.

\section{ÍNDICE}

Keywords: Society, State, civil society, identity, Angola

Palavras-chave: Sociedade, Estado, sociedade civil, identidade, Angola

\section{AUTOR}

\section{ARLINDO BARBEITOS}

Doutorado em Sociologia pela Universidade da Beira Interior (Covilhã, Portugal), é Professor Auxiliar do Departamento de Sociologia (DS) e Director do Centro Avançado de Estudos Africanos (CAEA) da Faculdade de Ciências Sociais (FCS) da Universidade Agostinho Neto (UAN). Além de investigador na área das Ciências Sociais e Humanas, é escritor membro da União dos Escritores Angolanos (UEA), sendo um dos seus fundadores em 10 de Dezembro de 1975.

Publicou as obras, textos esparsos e artigos seguintes: Angola-Portugal. Representações de si e de outrem ou o jogo equívoco das identidades (2010); Angola-Portugal: des identités coloniales equivoques. Historicité des representations de soi et d'autrui (2008); A sociedade civil, Estado e identidade em Angola (2005; 2008); Considerações críticas de um angolano sobre Fernando Pessoa (2004); «Prefácio», in David Birmingham, Portugal e África. Traduzido do inglês por Arlindo Barbeitos (2003); «Oliveira Martins, Eça de Queiroz, a raça e o homem negro», in Maria Emília Madeira Santos (coord.), A África e a instalação do sistema colonial, c. 1885- c. 1930 (2000); «O conceito de África e o direito de classificar: relação entre sujeito e objecto e a questão da identidade», Mulemba - Revista Angolana de Ciências Sociais (Luanda), vol. II, n.ํ 3, Maio de 2012, pp. 9-33; «O Mali. Destruição de um Estado africano na era global», Mulemba - Revista Angolana de Ciências Sociais (Luanda), vol. II, n.o 4, Novembro de 2012, pp. 179-190; «A desconstrução histórica do conhecimento exógeno africano. Elementos para uma leitura sistemática de $\mathrm{A}$ invenção de África. Gnose, filosofia e a ordem do conhecimento, do filósofo congolês V.Y. Mudimbe», Mulemba - Revista Angolana de Ciências Sociais (Luanda), vol. III, n.ํ5, Maio de 2013, pp. 141-149.

Publicou ainda as seguintes obras literárias: Na leveza do luar crescente (1999); Fiapos de sonho (1993; 1992); O rio. Estórias do regresso (1985; 1979); Nzoji, Sonho (1979); Angola, Angolê, Angolema (1976; 1974). Foi vencedor do «Prémio Nacional de Cultura e Artes», na disciplina de Ciências Humanas e Sociais, no ano de 2011. É membro do Conselho Científico da Mulemba Revista Angolana de Ciências Sociais.

arlindo_barbeitos@yahoo.com.br 